This item was submitted to Loughborough's Research Repository by the author.

Items in Figshare are protected by copyright, with all rights reserved, unless otherwise indicated.

\title{
Reduced bed material stability and increased bedload transport caused by foraging fish: a flume study with juvenile Barbel (Barbus barbus)
}

PLEASE CITE THE PUBLISHED VERSION

http://dx.doi.org/10.1002/esp.3592

\section{PUBLISHER}

(C) John Wiley \& Sons, Ltd

\section{VERSION}

AM (Accepted Manuscript)

\section{PUBLISHER STATEMENT}

This work is made available according to the conditions of the Creative Commons Attribution-NonCommercialNoDerivatives 4.0 International (CC BY-NC-ND 4.0) licence. Full details of this licence are available at: https://creativecommons.org/licenses/by-nc-nd/4.0/

\section{LICENCE}

CC BY-NC-ND 4.0

\section{REPOSITORY RECORD}

Pledger, Andrew G., Stephen P. Rice, and Jonathan Millett. 2019. "Reduced Bed Material Stability and Increased Bedload Transport Caused by Foraging Fish: A Flume Study with Juvenile Barbel (barbus Barbus)". figshare. https://hdl.handle.net/2134/16460. 
Reduced bed material stability and increased bedload transport caused by foraging fish: a flume study with juvenile Barbel (Barbus barbus).

Pledger, A.G. ${ }^{*}{ }^{1}$, Rice, S.P. ${ }^{1}$ and Millett, J. $^{1}$

${ }^{1}$ Loughborough University, Department of Geography, Loughborough University, Loughborough, LE11 3TU, UK

Email: A. G. Pledger (gyap@lboro.ac.uk)

*Department of Geography, Loughborough University, Loughborough, LE11 3TU, UK 


\section{Abstract}

The plants and animals that inhabit river channels may act as zoogeomorphic agents affecting the nature and rates of sediment recruitment, transport and deposition. The impact of benthic-feeding fish, which disturb bed material sediments during their search for food, has received very little attention, even though benthic feeding species are widespread in rivers and may collectively expend significant amounts of energy foraging across the bed. An ex-situ experiment was conducted to investigate the impact of a benthic feeding fish (Barbel Barbus barbus) on particle displacements, bed sediment structures, gravel entrainment and transport fluxes. In a laboratory flume changes in bed surface topography were measured and grain displacements examined when an imbricated, water-worked bed of 5.6-16 mm gravels was exposed to feeding juvenile Barbel (on average, $0.195 \mathrm{~m}$ in length). Grain entrainment rates and bedload fluxes were measured under a moderate transport regime for substrates that had been exposed to feeding fish and control substrates which had not. On average, approximately $37 \%$ of the substrate, by area, was modified by foraging fish during a four-hour treatment period, resulting in increased microtopographic roughness and reduced particle imbrication. Structural changes by fish corresponded with an average increase in bed load flux of $60 \%$ under entrainment flows, whilst on average the total number of grains transported during the entrainment phase was $82 \%$ higher from substrates that had been disturbed by Barbel. Together, these results indicate that by increasing surface microtopography and undoing the naturally stable structures produced by water working, foraging can increase the mobility of gravel bed materials. An interesting implication of this result is that by increasing the quantity of available, transportable sediment and lowering entrainment thresholds, benthic feeding might affect bedload fluxes in gravel-bed rivers. The evidence 
presented here is sufficient to suggest that further investigation of this possibility is warranted.

Keywords: Ecosystem engineering; Bedload transport; Barbel; Imbrication; Zoogeomorphology. 


\section{INTRODUCTION}

Animals, plants, fungi and microorganisms live within geomorphological systems of sediment production, transfer and deposition that help to explain their biogeography, ecology and evolution (Corenblit et al., 2007). Simultaneously the activities of biota can affect the nature and rates of geomorphological processes (Viles, 1988; Naiman et al., 2000; Butler, 1995; Reinhardt et al., 2010). While the potential importance of this biotic-abiotic interaction for Earth surface sediment dynamics has been widely discussed (Darby, 2009; Hession et al., 2010; Wheaton et al., 2011; Rice et al., 2012a), understanding of the impact of biota on sediment transport processes, landform generation and sediment yields remains rudimentary.

In fluvial systems, for example, recent reviews by Statzner (2011) and Rice et al. (2012b; their Figure 19.6) indicate that riverine fish and macroinvertebrate fauna can stabilise or destabilise bed sediments in various ways. Mechanisms include: (1) the secretion of biostabilising substances including silk; (2) alteration of bed topography with implications for near-bed flow resistance and entrainment hydraulics; and (3) direct modification of bed sediment characteristics relevant to entrainment and transport, including grain interlock, imbrication, grain size, sorting, sand:gravel ratio and grain protrusion. However, the zoogeomorphic agency of only a small number of animals has been investigated, including several salmonids (Field-Dodgson, 1987; Kondolf et al., 1993; Montgomery et al., 1996), hydropsychid caddisflies (Cardinale et al., 2004; Johnson et al., 2009); perlidae stoneflies (Statzner et al., 1996) and crayfish (Statzner et al., 2003A; Zhang et al., 2004; Johnson et al., 2011). These are a small proportion of potentially relevant animals and, in addition, the impacts that have been studied focus on a limited selection of the behaviours, activities and impact mechanisms that are likely to be important. For example, foraging for food 
amongst the surface layers of the river bed is a common feeding habit of riverine fish species. Ecological studies of foraging have noted impacts on sediment accrual (Pringle and Hamakazi, 1998), but the potential for foraging to affect bed stability and sediment fluxes is largely unstudied.

This study therefore investigated the impacts of a specialist benthic foraging fish, the European Barbel (Barbus barbus L.) (hereafter 'Barbel') on bed sediment structures, grain entrainment and bed material transport in an ex-situ, flume experiment. We compared the microtopography of gravel substrates which were water-worked and those which were water-worked then foraged by Barbel, and measured differences in grain entrainment and sediment yields when these substrates were then exposed to high flows. The specific aims of the study were to quantify and test the significance of: (1) the effect of foraging juvenile Barbel on the microtopography and surface structure of water-worked gravel bed materials; and (2) the effect of sediment disturbance by foraging Barbel on grain entrainment and bedload flux. Marked particles were tracked during periods of fish exposure to: (3) improve understanding of how individual particles are displaced during foraging.

We chose to study the impact of European Barbel for four reasons. First, Barbel are widely recognised as a bed foraging specialist (Piria et al., 2005). Second, owing to their prevalence across Europe (Kotlik and Berrebi, 2001), especially their presence in the middle reaches, or "Barbel Zone" (Huet, 1949), of many gravel bed rivers, the Barbel is a potentially prolific zoogeomorphic agent within European river systems. Third, Barbel are a large and aggregative species (Britton and Pegg, 2011) that satisfy Moore's (2006) criteria for effective ecosystem engineers. Fourth, two pioneering studies have established the potential importance of Barbel for river sediment disturbance and gravel movement. Statzner et al. (2003b) used ex-situ 
experiments in small ( $0.2 \mathrm{~m}$ wide) outdoor channels to investigate the impact of juvenile Barbel on unstructured, fine gravel beds. They measured a decrease in the critical shear stress (for gravel entrainment) of approximately $45 \%$ as the number of fish that were allowed to forage the bed was increased from zero to eight (Statzner et al., 2003b). Significant increases in mean bed elevation and the authors' observation that the fish heaped gravel into piles, led them to suggest that increased mobility was caused by the fish loosening the bed and increasing particle elevations. Subsequently, Statzner and Sagnes (2008) investigated the joint effects of Barbel, gudgeon (Gobio gobio) and the spiny-cheek crayfish (Orconectes limosus) and found that their net joint effects on sediment mobility were generally less than the sum of the impacts of the individual species. These experiments established the potential impact of Barbel on sediment transport, but the work contains some limitations that almost certainly affected their quantitative results: first the gravels were not waterworked so they were unstructured and therefore in an unrealistically mobile condition when the fish were added; second, during the experiments, trapped bedload was emptied back on to the bed after measurement, increasing the propensity for subsequent gravel movement; third, measures of bed topography were sufficient to surmise that Barbel affected gravel transport primarily by disturbing the bed, but were insufficient to provide further precision about the mechanisms involved.

\section{METHODOLOGY}

Fish husbandry and foraging behaviour

The experiments used juvenile Barbel that were two years old, hatchery-raised and born of wild fish stocks (River Trent, UK). At the hatchery, fish were only fed sinking 
food types, never floating pellets, to encourage natural benthic feeding behaviour. The Barbel used during experiments maintained a total body length of $0.195 \pm 0.009$ $\mathrm{m}$ and sub-aerial mass of $0.052 \pm 0.007 \mathrm{~kg}$ ( \pm 1 standard deviation). Fish were housed together in a 1000-litre holding tank containing filtered, oxygenated and dechlorinated mains water. Upon completion of an experiment, fish were transferred to a second, identical holding tank to prevent the re-use of individuals. Whilst in the holding tanks, fish were fed a varied diet of gamma-treated bloodworm Chironomus riparius and Coppens cyprinid pellet feed.

During experimental runs, when a fish was in the flume, the possible impact on behaviour of human movements within the laboratory was precluded by covering the glass walls of the flume so that the fish could not see out and by restricting access to a single operator. To limit any stress experienced by fish, flume water was regularly changed. Water quality parameters were monitored throughout each experimental period to ensure environmental conditions remained within Barbel tolerances, using a YSI 6600 V2 probe ( $\mathrm{pH}$, dissolved oxygen, conductivity) and a Tinytag PLUS 2 temperature sensor: temperature $=18.8^{\circ} \mathrm{C} \pm 0.9 ; \mathrm{pH}=8.8 \pm 0.1$; conductivity $(\mu \mathrm{S} / \mathrm{L})$ $=607 \pm 2.5$; dissolved oxygen $(\mathrm{mg} / \mathrm{l})=8.6 \mathrm{mg} / \mathrm{l} \pm 0.3$; dissolved oxygen $(\%)=99 \% \pm$ 1.5 (error $= \pm 1$ standard deviation).

Macroinvertebrate sampling in the River Idle, UK, where complementary field experiments were conducted, measured natural densities of benthic macroinvertebrate preys. These densities were used in a preparatory set of laboratory experiments that examined Barbel feeding behaviours across a range of feed types. It was found that bloodworm, seeded at the River Idle average prey density $\left(3548 \mathrm{~m}^{-2}\right)$ was associated with natural feeding behaviours and this food type and seeding density were therefore adopted in the main experiments. 
To establish that behaviour in the flume was similar to behaviour in a natural setting, underwater video of feeding fish was recorded in the River Idle and in the flume. In the Idle, underwater video was collected during three experiments. In each experiment, two cameras were used simultaneously to record two, four hour-long video records. In the flume, underwater video was collected during each experimental run, yielding six four-hour-long video records of foraging behaviours. Each four-hour-long video record corresponded to a specific "observation period", which we refer to during behavioural analyses. A total of 24 hours of field video and 20 hours of laboratory video were compared qualitatively and a detailed quantitative analysis was conducted based on a $30 \%$ sub-sample of the entire video record, using 72 randomly spaced one-minute intervals. Videography was used to identify the foraging behaviours utilised by Barbel and then to count the frequency at which these foraging behaviours were observed in the field and flume. The total number of times a specific foraging behaviour was used as a percentage of the total number of foraging events across all behaviours, was used to assess the similarity of foraging behaviours between field and flume.

The feeding behaviours of fish; that is, how they capture, process and ingest food particles, have been extensively studied, but little attention has been given to the manner in which fish interact with bed sediments whilst foraging. Therefore, we developed a classification scheme to describe the manner in which Barbel interact with river bed sediments and the specific feeding modes utilised whilst foraging. This scheme was built from our field and flume observations, with adaptations derived from previous studies (i.e. Janssen, 1976; 1978). We classified behaviours as "gulping", after Janssen $(1976 ; 1978)$ and defined three additional styles: "swim + gulping", "push + gulping" and "gulping + spit". 'Spit' is a standard description 
(Sibbing 1991), but here we only consider it when combined with other behaviours. During the "gulping" behaviour, fish swam slowly, making a series of sucks, directed towards areas of high prey densities. Grains were never sucked in with food items but grain orientations were adjusted. During the "swim + gulping" behaviour, multiple grains were moved in an unselective manner as fish placed their nose on the bed and swam forward quickly. This exposed previously covered bed material and prey, which were removed by gulping. During "push + gulping" behaviour, fish pushed discrete grains in a selective and controlled manner, exposing prey that were then captured by gulping. Linear feeding scars, orientated parallel with the flow, were created as fish displayed the "push" component of this behaviour. In the field, we observed these three same behaviours plus one additional behaviour, "gulping + spit". During this behaviour, large, adult fish suck in a mixture of bed sediment and food and separated them in the pharyngeal slit (Sibbing, 1991). Coarse sediments, too large to pass the branchial basket are spat from the mouth and deposited on the substrate surface. These feeding modes are consistent with those adopted by other Cyprinid species.

\section{Flume Setup}

Experiments were conducted in a tilting, glass-walled laboratory flume (10 m long $\mathrm{x}$ $0.3 \mathrm{~m}$ wide $\times 0.5 \mathrm{~m}$ deep). The flume setup did not mimic any prototype setting. An experimental enclosure $(5.0 \times 0.3 \times 0.5 \mathrm{~m})$ was created in the flume by installing permanent fences 4 and $9 \mathrm{~m}$ downstream from the flume inlet that were made of 0.01 x $0.01 \mathrm{~m}$ fine wire mesh (Figure 1A). Within this experimental enclosure, an observation area $(1.74 \times 0.3 \mathrm{~m})$, positioned so that its upstream edge was $5 \mathrm{~m}$ 
downstream from the flume inlet, was filled to a depth of $0.1 \mathrm{~m}$ with narrowly graded gravels. Ancillary experiments designed to investigate the largest grain sizes that could be moved by foraging juvenile Barbel showed that substrate size was limiting at $22 \mathrm{~mm}$ and therefore, a normally distributed grain-size distribution of 5.6-16 mm gravels was constructed $\left(D_{5}=6.1 \mathrm{~mm}, D_{50}=11 \mathrm{~mm}, D_{95}=15 \mathrm{~mm}\right)$. Fluvial gravels were sourced from the River Trent (Nottinghamshire) and were predominantly bladed (Sneed \& Folk, 1958) and well rounded (Krumbein, 1941). Within the observation area a smaller section, the "test bed", was the area used to evaluate changes in microtopography using repeat laser scanning (see Figure 1B and C for "test bed" location). Roughness boards elevated $0.1 \mathrm{~m}$ from the flume base were installed along the remainder of the flume length, both upstream and downstream of the observation area. These boards were covered with a mixture of fixed gravels between 8 and $32 \mathrm{~mm}$ in diameter that ensured the development of a fully turbulent, logarithmic boundary layer in the observation area.

Directly downstream of the observation area (Figure 1B and C), a custom-built bedload slot sampler (pit dimensions $=0.275 \times 0.125 \times 0.1 \mathrm{~m}$ ) was installed for making bedload measurements (Figure 2). The sampler had a flat steel plate $(0.275$ $\times 0.12 \times 0.003 \mathrm{~m}$ ) attached to the upstream edge of the pit, which facilitated recording and counting of mobile grains that approached the pit (Figure 2A). During periods when Barbel were in the flume, a cover of the same thickness $(0.003 \mathrm{~m})$ was positioned over the sampler so that the pit was inaccessible to fish (Figure 2B).

\section{Experimental procedure}


Twelve separate runs were conducted: six replicates for each of a "no-fish" control and a "with-fish" experimental treatment, referred to hereafter as 'control' and 'fish' runs, respectively. In each run there were three sequential elements: (1) a waterworking phase; (2) a treatment phase; and (3) an entrainment phase (Figure 3).

Hydraulic conditions during the three phases are described in Table 1. Measurements for characterising hydraulics during water-working and entrainment phases were obtained from velocity profiles collected with a Nixon Streamflo velocity meter V1.3 fitted with a high-speed probe, averaging over 60 seconds. Velocities were small $\left(0.01 \mathrm{~m} \mathrm{~s}^{-1}\right)$ during the treatment phase, and so a more sensitive Vectrino ADV ( $20 \mathrm{~Hz}$ sample rate; 60 second sample period) was used in preference to the Nixon meter. To ensure consistency between the two instruments a comparison test was performed in which both instruments were set up to measure streamwise velocity in essentially the same interrogation volume, simultaneously; that is, the Nixon was set up immediately downstream of the target volume of the side-facing Vectrino. There was no significant difference in measured mean velocity over a range of velocities.

Profiles were collected above the centre of the test bed with point measurements every $2.5 \mathrm{~mm}$ throughout the bottom $20 \%$ of the flow and at increasing vertical increments above. Profiles consisted of 23, 26 and 29 points for the flows in phase 1 , 2 and 3, respectively. Six profiles were collected outside of the main experimental programme for the water-working and entrainment flows and one profile was collected for the treatment phase. These profiles were used to estimate near-bed shear stresses using the law of the wall (Biron et al., 1998; Robert, 2003), corrected for sidewall drag using Williams' (1970) empirical approach $\left(\tau_{0}\right)$. Dimensionless Shields' parameters $(\theta)$ were calculated as: 
$\theta=\frac{\tau_{0}}{\left(p_{s}-p\right) g D_{50}}$

Where $\tau_{0}$ is the calculated shear stress, $p_{s}$ is the density of sediment $\left(=2650 \mathrm{Kg} \mathrm{m}^{-}\right.$

$\left.{ }^{3}\right), g$ is the acceleration due to gravity $\left(=9.81 \mathrm{~m} \mathrm{~s}^{-2}\right)$ and $D_{50}$ is the median grain size $(=11 \mathrm{~mm})$.

\section{Phase 1: Water-working}

Twenty-five grains in each of the three half-phi size classes $(5.6-8,8-11,11-16 \mathrm{~mm})$ used to construct the sediment mixture were marked with uniquely identifiable reference points and randomly distributed over the test bed surface. Grains were added to the sediment mix in such a way that the surface grain-size distribution remained un-altered. These grains were subsequently used in particle tracking measurements.

The flume was slowly filled with water to prevent sediment disturbance, flume slope was modified and the tail weir and pump speed altered to generate a flow whereby bed shear stress was slightly above the critical threshold required for particle mobility (Table 1). The unstructured, screeded bed was allowed to water-work for two hours during which time sediment that collected in the bedload slot sampler (Figure 2A) was re-introduced upstream of the observation area to encourage the development of a natural, dynamic bed structure rather than the formation of a non-evolving, static armour. After the 2-hour water-working period, the flume pump rate was gradually reduced until discharge reached zero and the flume was allowed to drain slowly to preserve grain fabric and bed structure. In all runs the test section was then laser scanned to obtain bed elevation data for characterising microtopography and bed 
structure (details below in the Measurements sub-section) and photographed to record the positions of marked particles (Figure 3).

\section{Phase 2: Treatment}

In the six fish runs, the slot sampler cover was put in place (Figure 2B) and the downstream half of the observation area was seeded with 1064 gamma radiated larval chironomidae (hereafter bloodworm) in an even distribution over the bed, at the density determined by the ancillary experiments described above (3548 $\mathrm{m}^{-2}$ ). Once the bloodworms were in place the flume was slowly filled. A low flow suitable for juvenile Barbel was created (mean velocity $=0.01 \mathrm{~m} \mathrm{~s}^{-1}$; Table 1 ). This flow was insufficient to either cause the animals stress or mobilise bed sediments (Shields number $=0.0005 ;$ Table 1$)$. The process of slowly filling the flume gently washed the bloodworms into interstitial gaps between grains, where prey would be found to occur in a natural system. A single juvenile Barbel was then placed in an acclimatisation area $(2.0 \times 0.3 \mathrm{~m}$; Figure $1 \mathrm{~A})$ separated from the experimental area by a temporary fence. After one hour, the temporary fence was carefully removed, allowing the fish free access to the $5 \mathrm{~m}$ long experimental enclosure. This signified the beginning of an experiment, which was allowed to run for 4 hours (Figure 3A).

Under summer-time conditions within natural systems, Barbel tend to be crepuscular, becoming active at sunrise and sunset when they forage within gravel substrates for macroinvertebrate prey (Baras, 1995; Lucas \& Batley, 1996). For this reason, each experiment began 4 hours before sunset and was allowed to run until darkness. During experiments, all artificial light sources were removed and blinds and skylights were fully opened to allow light decay at natural rates. Following the four hour fish- 
exposure period, the fish was carefully corralled back into the acclimatisation area and removed from the flume. Each treatment run used a different individual fish. At the end of each fish run, a second set of scans and photographs of the test bed were obtained. In preparation for the entrainment phase, the pit trap cover was removed and the entrainment plate was reattached, so that trap configuration was changed from that shown in Figure $2 \mathrm{~B}$ to that in $2 \mathrm{~A}$.

In the six control runs, fish were not added (Figure 3B). The flow condition for phase 2 was insufficient to affect bed sediments with a Shields number of 0.0005 , well below the threshold for motion or entrainment, and we saw no evidence of particle movements, vibration or rearrangement at this flow. It was therefore unnecessary to expose the bed to the entire 5 hour duration used in the fish runs. However, it was necessary to run the flow for some period so that the draining and refilling operations necessary between phases 1-2 and 2-3 in the fish runs were duplicated in the control runs too, in case these operations had any impact on bed sediment characteristics. Therefore, the flume was carefully filled in the usual way and the phase 2 flow was run for ten minutes, after which the flume pump rate was gradually reduced until discharge reached zero and the flume was allowed to drain slowly to preserve bed structures. Scans and photographs of the test bed were then captured for a second time, as in the fish runs. Collection of scans and photographs during control runs provided data for establishing minimum discernible differences in surface elevation data and grain positions, required for DEM and grain tracking analyses, respectively (see Data analysis section below).

\section{Phase 3: Entrainment}


In both fish and control runs, flume slope, pump speed and tailgate height were then altered and the flume was filled carefully for the final time. In this phase, the flow had the highest bed shear stress, which exceeded the critical level for particle mobility (Shields number $=0.031 ;$ Table 1 ) such that there was moderate entrainment. An underwater video camera (Inspektor 1 Video Inspection Camera by RCU Underwater Systems) positioned downstream of the pit, looking upstream at the bare steel entrainment plate, provided a constant video record of mobile grains leaving the observational area. Counts of these grains were used to quantify entrainment rates. The entrainment phase lasted for two hours (Figure 3).

\section{Measurements of bed surface microtopography, particle movements and bedload characteristics}

\section{Bed elevations and bed structures}

Bed elevations were measured using a laser scanner (Konica-Minolta non-contact 3D Digitiser Vivid 910) mounted above the flume over the area of the test bed (0.41 $\mathrm{m}$ long and $0.26 \mathrm{~m}$ wide or approximately $2.1 \times 1.3$ fish lengths). The scans, consisting of approximately 260,000 irregularly spaced $x, y$ and $z$ coordinates with an average $x-y$ spacing of $1 \mathrm{~mm}$, were used to derive Digital Elevation Models (DEMs) of the test bed surfaces. Six discrete reference points provided elevation control for the rectification and scaling of these DEMs and consisted of $8 \mathrm{~mm}$ diameter rebar spigots which protruded from bed (Figure 1B and C). Point cloud data (4 scans per test bed) were rectified using Polygon Editing Tool, merged in ArcGIS৫ v.9.2 and converted into elevation data within Rapidform. These elevation models were then converted into raster DEMs using a kriging interpolation algorithm and subsequently 
cropped within ArcGISC v.9.2. All scans were made with the flume in a horizontal (zero slope) position, so that DEM detrending was unnecessary. All topographic and structural analyses of the DEMs were performed in ArcGIS@ v.9.2.

\section{Particle tracking}

Photographs for use in particle tracking were taken using a Canon IXUS 105 camera and imported into ArcGISC v.9.2 where they were rectified with DEM equivalents. Reference points on the grains were used to extract two-dimensional (x-y) vectors, corresponding to the location of grains before and after the treatment phase. Vector 1 was subtracted from vector 2 and the resultant resolved to determine the total displacement and direction of each grain's movement.

\section{Particle entrainment and bedload flux}

Quantifying the threshold of incipient motion is notoriously difficult, primarily due to its subjective nature (Neill and Yalin, 1969; Buffington and Montgomery, 1997). In this case, particle entrainment was quantified by counting the number of grains that left the observation area during two hours of the steady entrainment flow. Counting was based on a $30 \%$ sub-sample of the entire video record using 36 regularly spaced one-minute counts separated by 2.4 minute intervals. Grain counts were made by a single operator from the video of the "entrainment plate" described above. During the entrainment phase, bedload measurements were made every 10 minutes by emptying the pit and weighing the trapped sediment. Sediment flux and unit 
cumulative mass for the two-hour period were obtained from the bedload measurements.

\section{Data analysis}

\section{Fish behaviour}

The prevalence of different feeding behaviours, and the differences in this prevalence between Barbel in the River Idle and the flume was tested using ANOVA. We calculated the proportion of time spent on each of the four feeding behaviours, for each observation period, in each environment (River Idle or flume). Where we observed Barbel feeding, we counted each observation period as a separate replicate giving four replicates for the River Idle and five replicates for the flume. Data were angular transformed before analysis to conform to the assumption of homoscedasticity. We tested for the main effect of 'behaviour type' and the interaction between 'environment' and 'behaviour type', both were fixed effects.

In the flume, fish did not adopt "gulping + spit" foraging because the ability of fish to implement this behaviour is dependent on the size of their mouth, relative to the size of bed material (Lammens \& Hoogenboezem, 1991). During flume experiments, the smallest grain size in the experimental sediment mixture was large relative to the size of the juvenile fishes' mouths, and therefore we did not see this foraging behaviour. When comparing behavioural data, to ensure that we were comparing like with like, we excluded data for the "gulping + spit" style. 
Topographic changes due to Barbel foraging were quantified by creating Digital Elevation Models of Difference (DoDs): surface DEMs before and after exposure to Barbel were subtracted from one another to determine the fishes' effect on bed surface topography. To quantify the minimum discernible difference, DoDs were also calculated from DEMs obtained in the equivalent six pairs of scans collected at the end of phase 1 and phase 2 during control runs (Figure 3B). Estimated differences in these scans accounted for both experimental errors associated with draining and refilling the flume and processing errors associated with the capture, rectification and interpolation of DEMs from the laser scanner point clouds. This analysis revealed that the maximum calculated elevation difference was $0.6 \mathrm{~mm}$. We therefore applied an error factor of $\pm 1 \mathrm{~mm}$ as a liberal estimate of the minimum discernible difference in surface elevation.

Topographic differences exceeding the $\pm 1 \mathrm{~mm}$ threshold were considered to be the result of fish foraging. Foraging disturbance was partitioned into four discrete categories: "surface rearrangement" (positive and negative), was defined as a topographic change greater than the minimum discernible difference $( \pm 1 \mathrm{~mm})$ but less than $\pm 11 \mathrm{~mm}$, the median diameter of the bed material. Topographic changes greater than $11 \mathrm{~mm}$ may reflect displacement of individual grains, rather than their insitu rearrangement and were categorised as "surface gain" if the elevation difference was positive or as "surface retreat" if the difference was negative.

During the treatment phase in fish runs, Barbel disturbed parts of the test bed, but never all of it. Observations indicate that the spatial extent of disturbance was related to the length of time of exposure and it is likely that given sufficient time, all of the bed would have been disturbed. Therefore, measured disturbance areas are a function of the four-hour exposure period, so that our measurements of disturbance 
area are specific to the particular experimental protocol. While the areal amount of disturbance is interesting, of greater generic interest is the nature of that disturbance, its magnitude and how it affects bed sediment structures within those patches that were disturbed. For this reason, when quantifying surface properties before and after exposure to Barbel, we used the DoDs to identify and mask out in ArcGISC v.9.2 those areas of the before and after DEMs where disturbance was less than the \pm 1 $\mathrm{mm}$ threshold.

Within the retained, disturbed sections, we measured and compared several surface properties. Standard deviations of surface elevations were used as a surrogate for microtopographic roughness (Aberle \& Smart, 2003). Data were tested for normality using Shapiro-Wilkes tests and a paired t-test was used to compare pre- and postforaging mean values. We also quantified and compared the degree of particle structuring or imbrication in the stream-wise direction using Smart et al.'s (2004) inclination index $I_{l}$, which compares the proportion of positively sloping relative to negatively sloping DEM cells, for a given lag distance, $l=2 \mathrm{~mm}$ in this case:

$I_{l}=\frac{p_{l}-n_{l}}{p_{l}+n_{l}+z_{l}}$

where, $p_{l}$ is the number of positive slopes, $n_{l}$ the number of negative slopes and $z_{l}$ the number of zero slopes. Water-worked substrates tend to display an asymmetric distribution of inclinations in a stream-wise direction, purely as a function of imbrication (Smart et al., 2004; Hodge et al., 2009). Unstructured surfaces (equal numbers of positive and negative inclinations) are likely to maintain an index value around zero, whilst heavily structured fluvial fabrics tend towards an index value of +1.0 (Smart et al., 2004; Millane et al., 2006). A negative inclination index is indicative of a bed in which typical imbrication is reversed. Data were tested for 
normality using Shapiro-Wilkes tests and a paired t-test was used to compare preand post-foraging mean values.

Characteristics of sediment displacements by foraging Barbel

Error analyses for particle tracking measurements were performed using photographs before and after the 10-minute treatment phase in control runs. Estimated errors accounted for experimental errors associated with draining and refilling the flume and processing errors associated with the capture and rectification of images. Across all grain sizes, the maximum displacement value measured during control runs was $2 \mathrm{~mm}$ in the planimetric (x-y) plane and only distances exceeding this value were included in the analysis of marked grain displacement during fish runs. Simple summary statistics of the vector displacements greater than $2 \mathrm{~mm}$ were used to investigate the characteristics of sediment movements by fish.

\section{The effect of foraging on entrainment and bedload}

Direct comparisons were made between control and fish treatments to quantify the effects of foraging on sediment transport. We first tested the impact of foraging immediately after the treatment phase (i.e. using the first measured average bedload flux between $t=0$ and $t=600$ seconds in phase 3 ). This is a particularly important test of the impact of the fish because we expected (and observed) bed restructuring as phase 3 progressed and therefore a decline in transport caused by the entrainment flow. We also assessed the impact of fish on the total number of transported grains and unit cumulative mass deposited in the bedload trap during the 
entrainment phases. All data were tested for normality (Shapiro-Wilkes test), and analysed using un-paired, two-tail t-tests or Mann-Whitney U-tests as appropriate. To determine the temporal persistence of any effect on sediment flux we also tested for the impact of fish across the entire measurement time series (to $t=7200$ seconds). This was done using a Linear Mixed Model in which the potential for auto-correlation between time points was accounted for with a compound symmetry covariance structure.

The relatively low replication $(n=6)$ results in an increased associated risk of a type II error. To account for this, a significance ( $\alpha$ ) value of 0.10 was used during all hypothesis testing. Despite this increasing the risk of a type I error, it was considered appropriate given the low number of replicates and the exploratory, novel nature of the experiments.

Data analysis was carried out using IBM SPSS Statistics v21.0 (IBM Corp. 2011).

\section{RESULTS}

\section{Foraging behaviour}

In the flume, juvenile Barbel utilised the majority of foraging behaviours that Barbel used in the River Idle (Figure 4). There were statistically significant differences between the proportions of time spent utilising the different feeding behaviours (ANOVA: $F_{2,21}=131.59, P<0.001$ ). The Barbel spent the majority of their feeding time using the 'push + gulp' behaviour (Flume $=62 \%$; River Idle $=64 \%)$. In the flume they spent $37 \%$ whilst in the River Idle they spent $34 \%$ of their time using 'gulping' behaviour, and the least amount of time using 'swim + gulping' (flume $=1 \%$; River 
Idle $=1 \%)$. There was no significant difference in these patterns between the River Idle and the flume (ANOVA: environment $x$ behaviour $-F_{3,21}=0.25, P=0.894$ ).

When the results for individual experiments were compared, the behaviour of one fish differed significantly from that of the other fish, in that it fed substantially less. In the six fish runs, the average number of feed events per 72 minutes was 19.7 (standard deviation $=13.0)$, but this particular fish fed only three times, approximately four times less than the next least active and twelve times less than the most active. The run containing this 'outlier' fish was therefore removed from subsequent analyses.

The effect of foraging on river bed microtopography and surface structures

On average, $36.9 \%$ of the test bed area was modified (i.e. elevation change $> \pm 1 \mathrm{~mm}$ ) during the four hour exposure period (Figure 5). Within the modified area the majority of the disturbance (96\%) fell within the $\pm 11 \mathrm{~mm}$ to $\pm 1 \mathrm{~mm}$ categories (surface rearrangement). Juvenile Barbel were capable of foraging at depths of $20 \mathrm{~mm}$ whilst the maximum increase in surface elevation as a result of feeding was $24 \mathrm{~mm}$.

Foraging by Barbel led to a significant increase in the standard deviation of measured bed elevations (a surrogate for substrate microtopographic roughness) within the disturbed areas, when compared with the same areas of water-worked substrate before exposure to fish (Table 2; Paired t-test: $t_{4}=-5.73, P<0.001$ ).

Foraging also affected the structure of the gravel bed. The initial water-working created imbricated surface texture with an asymmetric distribution of inclinations consistent with values observed in natural, gravel bed rivers where values of the 
inclination index I, typically range between 0.03 and 0.18 (Millane et al., 2006). Foraging by Barbel had a statistically significant impact on the inclination index (Table 2; Paired t-test: $\mathrm{t}_{4}=3.97, P=0.004$ ), reducing the mean water-worked value from 0.035 to -0.075 at the end of the treatment phase.

\section{Characteristics of sediment displacements by foraging Barbel}

Retrieval rates for marked particles were generally low at the end of the waterworking phase and varied as a function of clast size $(5.6-8 \mathrm{~mm}=0 \% ; 8-11 \mathrm{~mm}=$ $46.1 \% ; 11-16 \mathrm{~mm}=37.2 \%)$. Finer clasts fell into interstitial spaces between larger grains and were more frequently transported downstream. An average of twelve marked 8-11 mm grains and nine marked 11-16 mm grains were available for tracking measurements during the treatment phase. In general the low retrieval rates reflect the mobility of the three size fractions during phase 1 , after which a significant proportion of marked clasts were found in the bedload sampler. This emphasises the need to water-work sediments in order to obtain realistic assessments of their stability.

Foraging fish displaced marked particles by amounts that far exceeded the minimum discernible displacement determined from control runs $(2 \mathrm{~mm})$. On average, fish moved smaller $(8-11 \mathrm{~mm})$ clasts farther than larger $(11-16 \mathrm{~mm})$ clasts. The maximum displacement of 8-11 mm grains was $301 \mathrm{~mm}$ and of 11-16 mm grains was $95 \mathrm{~mm}$. The respective averages were 41 and $31 \mathrm{~mm}$ (Table 3). The majority of all grain displacements occurred in the upstream direction. However, smaller clasts tended to be moved mostly upstream, whilst larger clasts tended to be moved mostly downstream (Table 3). The percentage of all marked grains that were recovered from 
the sediment surface at the end of the treatment phase were $33 \%$ and $16 \%$ for $8-11$ $\mathrm{mm}$ and 11-16mm grains, respectively, which means that, on average, eight and four grains in each size class were recovered during each experiment.

The effect of foraging on entrainment and bedload

Comparing bedload flux estimates between the control and fish runs reveals that foraging Barbel had a significant impact. Over the two-hour period, mean bed load transport rates declined from $1.6 \times 10^{-3}$ to $4.4 \times 10^{-4} \mathrm{~kg} \mathrm{~m}^{-1} \mathrm{~s}^{-1}$ in fish runs and from 1 $\times 10^{-3}$ to $3.9 \times 10^{-4} \mathrm{~kg} \mathrm{~m}^{-1} \mathrm{~s}^{-1}$ in control runs (Figure 6). The pattern of decline was expected, as less stable particles were quickly entrained and the bed became increasingly structured under the entrainment flow. Importantly, the initial bedload flux between 0 and $600 \mathrm{~s}$, was significantly greater in fish than in control runs (Unpaired t-test: $\left.\mathrm{t}_{9}=-1.96, P=0.081\right)$. Considering the full time series out to the final 10 minute measurement between 6600 and 7200 seconds (Figure 6), this impact was persistent: there was a significant effect of time $\left(\mathrm{LMM}: \mathrm{F}_{11}=11.18, P=<0.001\right)$ and a significant effect of fish treatment $\left(\mathrm{LMM}: F_{1}=4.02, P=0.051\right)$, but no significant interaction between the two $\left(L M M: F_{12}=1.59, P=0.102\right)$.

The relatively gross measurements of flux (averaged over 10-minute intervals) almost certainly lead to an underestimation of the Barbel effect. Extrapolation of the data in Figure 6 toward time $=0$, suggests a much greater initial difference in bedload transport rates between fish and control runs. Our results are therefore conservative, because they integrate the initial flux responses over the first $600 \mathrm{~s}$ of entrainment.

During the entire two hour entrainment phase, the cumulative mass of transported bedload (Figure 7A) and the total number of entrained clasts (Figure 7B) were higher 
from foraged beds. However, only the increase in grain count was statistically significant (total bedload, Mann-Whitney $\mathrm{U}$ test: $\mathrm{U}_{9}=7.0, P=0.14$; number of grains moved, Un-paired t-test: $\left.\mathrm{t}_{9}=-4.44, P=0.0016\right)$.

\section{DISCUSSION}

Foraging by Barbel caused significant changes to the microtopography and structure of water-worked gravel substrates, increasing microtopographic roughness while essentially 'undoing' imbrication associated with water-working. In addition, grain entrainment counts and bedload sediment fluxes were higher from beds that had been exposed to foraging barbel, prior to reorganisation of the bed into more stable configurations by the entrainment flow. Bedload flux during the first ten minutes of the entrainment flow was on average $60 \%$ higher for beds that had been foraged by juvenile Barbel for four hours. Although we have no direct, independent measurements of the impact of foraging on the entrainment stresses for individual grains, it is reasonable to propose that the measured changes in bed structure explain the increased sediment production; that is, that foraging reduced the stability of individual grains by reducing imbrication and increasing protrusion. As far as we are aware this is the first demonstration and quantification of the impact that foraging fish can have on the fabric and thence stability of water-worked gravel substrates and bedload transport.

Foraging by Barbel affected the river bed in a different way to that previously documented for other behaviours and animals: for example, redd-building by salmonids (e.g. Gottesfeld et al., 2008), pit-digging by signal crayfish (Johnson et al., 2010:2011) and mound-building by North American chub (Lachner, 1952). The 
majority of microtopographic alterations fell within the \pm 11 to $\pm 1 \mathrm{~mm}$ disturbance categories, with only a very small proportion of all elevation changes exceeding the diameter of the $D_{50}(11 \mathrm{~mm})$. This suggests that feeding Barbel predominantly foraged within the surface layer and modified microtopography and structure by moving individual grains and altering their attitude and position, rather than by digging substantial pits or creating mounds of multiple grains (as, for example, in redd building).

Changes in bed sediment characteristics caused changes in bedload flux.

Three arguments suggest that the measured changes in bed sediment characteristics can explain the observed increase in bed load flux during fish runs. First, the degree of stabilising, particle imbrication was reduced by foraging fish. Imbrication is regarded as a stabilising phenomenon because individual particles are in attitudes that minimise drag and because grain-on-grain interaction demands that individual grains have to be pried loose from the constraints of neighbouring particles (Komar and Li, 1986; Church et al., 1998; Church, 2010). Feeding essentially undid water-worked imbricate structures, as indicated by the significant change in values of Smart's inclination indices from mean positive to mean negative values (Table 2). The shift from positive to negative values indicates a reversal of inclinations, so that after foraging, bed particles showed a propensity to dip downstream rather than upstream. The increased grain entrainment counts suggest that this rendered more clasts relatively more mobile, probably by increasing the drag on individual grains, by increasing grain protrusion and by freeing grains from the constraints of their neighbours. 
Our observations suggest why benthic feeding fish may be generally effective in this regard. During fish runs, particle tracking showed that $63 \%$ of all displaced grains were moved in an upstream direction, supporting a general observation made in video analysis that Barbel predominantly forage while facing upstream. This observation was consistent with analysis of foraging behaviours in the River Idle, where Barbel and other observed species, always foraged whilst facing upstream. By feeding in this way, foragers are swimming against the main current which helps them hold position or make deliberate, controlled movements. Barbel are particularly effective in this regard due to the species' unique physiology; the supressed, elongated body is streamlined to minimise drag, whilst the fish's large pectoral and pelvic fins are angled to generate down-thrust, so as to hold the fish in position close to the river bed. The upper lobe of the tail is generally larger than the lower, which generates uplift, angling the nose downward whilst swimming. This positioning is aided by flows over the Barbel's shovel-like head and "hump", located between the dorsal fin and the head, which generates downward pressure (Giles, 2002). Barbel are therefore adapted to feed from the bed whilst facing upstream against the main current and this characteristic of behaviour will likely influence the nature of their effect on bed sediment structures. In particular this would allow them to easily penetrate the interstices between upstream dipping, imbricated grains to force them apart and rotate them into vertical positions or turn them through their pivot angles into obtuse positions.

Second, significant increases in the standard deviation of surface elevations, after exposure to fish, imply the production of a less packed surface fabric, in which some grains are likely to have become more exposed to the flow; for example, by displacement of neighbours, by rotating grains through their pivot angles into vertical 
positions, or by direct elevation gain. It is reasonable to hypothesise that this may have increased the mobility of individual grains by increasing the degree of protrusion and thence drag upon them. Modest increases in protrusion may be important because grain entrainment is sensitive to protrusion (Fenton and Abbott, 1977).

Third, clast tracking analyses showed that fish displaced some whole clasts during foraging by mean values of approximately $35 \mathrm{~mm}$, up to a maximum distance of 301 $\mathrm{mm}$. Whole grain displacements are important, not so much because they represent a sediment flux, but because affected grains might come to rest in relatively proud, less stable positions on top of the bed surface where they are more susceptible to entrainment in subsequent high flows.

Implications of fish foraging behaviour for sediment transport in rivers

In this flume study we found clear and significant differences $(\alpha=0.10)$ in sediment flux and the total number of transported grains during the 2-hour entrainment period, when comparing data derived from substrates which had been exposed to foraging juvenile Barbel, and those that had not. We consider this to be reasonable evidence that disturbance of river bed sediments by foraging Barbel might have an effect on river bed stability and thence bedload transport fluxes within natural river systems. The potential significance of this interesting result warrants further investigation including across a variety of ecological situations (e.g. considering species type and fish size as zoogeomorphic controls). In addition, there is a need to map the spatial extent and temporal persistence of foraging by barbel and other benthic feeding fish species to identify when and where foraging impacts might be expected. Recalling the findings of Statzner and Sagnes (2008) that net interspecific effects on sediment 
mobility were generally less than the sum of the impacts of the individual species, a further challenge for up-scaling is to tackle the question of how community interactions and feedbacks to the physical system affect zoogeomorphic potential (cf. Viles et al., 2008).

Beyond the exciting results presented here, three arguments support the value of further work. First, benthic foraging is a common feeding behaviour in river environments. For example, of 309 European species used in the European Commission's FAME initiative (Development, Evaluation and Implementation of a Standardised Fish-based Assessment Method for the Ecological Status of European Rivers), 96 (31\%) were categorized as having a benthic feeding habit (Noble et al., 2007; FAME consortium, 2004). As a second example consider the feeding behaviours of Cyprinids (Cyprinidae), the family that includes Barbel and which contains more species than any other freshwater family in the UK (19 of 53). Dietary analyses of the thirteen most common European Cyprinid species (Lammens \& Hoogenboezem, 1991) found in the UK, showed that twelve of them (92\%) sought sustenance from river bed sediments. Of these twelve species, seven (58\%) derived the majority of their food from the bed whilst the remaining five species (42\%) fed from the bed regularly. A compilation of available information about the feeding behaviours of these thirteen species (Table 4) confirms the dietary analysis of Lammens \& Hoogenboezem (1991), and leads to the observation that the majority of common UK Cyprinid fish will feed from the bed, at least some of the time, to exploit an available food resource. That many species are part-time benthic feeders reflects the need for many fish species to compensate for changes in food availability by being adaptable, including shifting from pelagic to benthic feeding behaviours if an opportunity arises. 
That benthic foraging is not rare or limited to a small group of animals is further supported by incidental observations made during several ecological studies which indicate that other fish in the same Cyprinidae family of freshwater fish can affect river bed sediment composition: King Carp (Cyprinus carpio) resuspend fine sediment whilst foraging for food (Breukelaar et al., 1994; Parkos et al., 2003; Chumchal et al., 2005; Miller \& Crowl, 2006; Roozen et al., 2007; Matsuzaki et al., 2009) and other benthic feeders such as Bream (Abramis brama), Tench (Tinca tinca) and Ruffe (Gymnocephalus cernus) are acknowledged to modify fine sediment accrual rates (Persson and Svensson, 2006).

Second, foraging fish are spatially widespread. For example, they can be found in all four of the generic "river zones" established by Huet (1949) in his longitudinal zonation scheme for Western European rivers. In the UK, Cyprinid benthic feeders are present in Huet's Grayling zone, Barbel zone and Bream zone (Table 4). In the Trout zone, non-Cyprinid benthic feeders are present, e.g. Grayling Thymallus thymallus. Indeed, most of the Salmonidae that characterise the Trout zone feed opportunistically from the bed (Forrester et al., 1994; Amundsen et al., 1999).

Third, foraging fish must feed all year round, albeit at variable rates depending on water temperature and fish metabolism (Baras, 1995). Foraging is therefore likely to cause bed disturbance of variable magnitude but with some baseline persistence through time.

What little work has been published on the role of fish as zoogeomorphic agents has focused on the disturbance caused by seasonal redd-building in suitable spawning gravels. This is clearly an important mechanism by which fish can substantially alter bed conditions, near-bed hydraulics and sediment transport (Field-Dodgson, 1987; 
Kondolf et al., 1993; Montgomery et al., 1996; Peterson \& Foote, 2000; Moore et al., 2004; Moore 2006; Gottesfeld, 2008; Hassan et al., 2008; MacDonald et al., 2010; Albers and Petticrew, 2013). Foraging may be another important zoogeomorphic mechanism with implications for bed load sediment flux at local and larger scales, not least because of its potential spatial reach and temporal persistence.

\section{CONCLUSION}

Foraging juvenile Barbel modified water-worked surface gravels, undoing stable imbricate structures and increasing microtopographic roughness. These changes corresponded with an average increase in grain entrainment counts of $82 \%$ and in bed load flux of $60 \%$ under entrainment flows. We have argued that the changes in bed material organisation and structure are the most likely explanation for the increased sediment mobility. The foraging behaviour of Barbel predominantly involves swimming upstream against the current, so that the upstanding underside of imbricated clasts can be lifted and rolled over during their search for food. Our results indicate that such behaviour is an effective mechanism for altering bed material microtopography and fabric, undoing stabilising structures and rendering bed grains more mobile. It is clear that ex-situ zoogeomorphic experiments like those reported here must therefore simulate natural water-worked bed materials in order to provide meaningful information. Results from this study support and extend the observations made by Statzner et al. (2003b) and Statzner and Sagnes (2008) regarding the zoogeomorphic capabilities of Barbel. Our results allow us to hypothesise that foraging fish, which are extensive in space and time and which are abundant, might 
affect bed load sediment transport in gravel-bed rivers, but this requires testing in-situ, across a range of ecological and environmental conditions.

\section{Acknowledgements}

We would like to thank the Barbel Society for providing financial support; Matthew Johnson for general help and advice; Stuart Ashby and Barry Kenny for help with equipment; and Alan Henshaw (National Coarse Fish Rearing Unit Calverton) for kindly providing us with the Barbel. AGP was in receipt of a Loughborough University Faculty Studentship. We would also like thank two reviewers for their very helpful comments and suggestions as well as the guest editors for their encouragement and guidance. 


\section{References}

Aberle J, Smart GM. 2003. The influence of roughness structure on flow resistance on steep slopes. Journal of Hydraulic Research 41: 259-269.

Adámek Z, Obrdlík P. 1977. Food of important cyprinid species in the warmed barb zone of the Oslava river. Folia Zoologica 26: 171-182.

Albers SJ, Petticrew EL. 2013. Biogeomorphic impacts of migration and disturbance: Implications of salmon spawning and decay. Geomorphology 202: 43-50.

Amundsen PA, Bergersen R, Huru H, Heggberget TG. 1999. Diel feeding rhythms and daily food consumption of juvenile Atlantic Salmon in the River Alta, northern Norway. J. Fish. Biol. 54: 58-71.Baras E. 1995. Seasonal activities of Barbus barbus: Effect of temperature on time-budgeting. Journal of Fish Biology 46: 806-818.

Baras E. 1997. Environmental determinants of residence area selection by Barbus barbus in the River Ourthe. Aquatic Living Resources 10: 195-206.

Baras E, Cherry B. 1990. Seasonal activities of female barbel Barbus barbus in the River Ourthe (Southern Belgium), as revealed by radio tracking. Aquatic Living Resources 3: 283-294.

Bischoff A, Freyhof J. 1999. Seasonal shifts in day-time resource use of 0+ barbel, Barbus barbus. Environmental Biology of Fishes 56: 199-212.

Bohl E. 1980. Diel pattern of pelagic distribution and feeding in planktivorous fish. Oceologia 44: 368-375.

Bohl E. 1982. Food supply and prey selection in plantivorous Cyprinidae. Oceologia 53: 134-138.

Brabrand A. 1984. Microhabitat seggregation between bream (Abramis brama (L.)) and white bream (Blicca bjoerkna (L.)) in a mesotrophic lake, SE Norway. Pol. Arch. Hydrobiol. 31: 99-108.

Breukelaar AW, Lammens E, Breteler J, Tatrai I. 1994. Effects of benthivorous bream (Abramis brama) and carp (Cyprinus carpio) on sediment resuspension and concentrations of nutrients and chlorophyll-a. Freshwater Biology 32: 113-121. 
Britton JR, Pegg J. 2011. Ecology of European Barbel Barbus barbus: Implications for River, Fishery, and Conservation Management. Reviews in Fisheries Science 19: 321-330.

Buffington JM, Montgomery DR. 1997. A systematic analysis of eight decades of incipient motion studies, with special reference to gravel-bedded rivers. Water Resources Research 33: 1993-2029.

Butler DR. 1995. Zoogeomorphology Animals as geomorphic agents. Cambridge University Press, UK.

Cala P. 1970. On the ecology of the Ide Idus idus L. in the river Kavlingean, south Sweden. Rep. inst. Freshwat. Res. Drottningholm 50: 45-99.

Cardinale BJ, Gelmann ER, Palmer MA. 2004. Net spinning caddisflies as stream ecosystem engineers: the influence of hydropsyche on benthic substrate stability. Functional Ecology 18: 381-387.

Chappaz R, Brun G, Olivari G. 1987. Mise en évidence de différences de régime allimentaire dans une population d'ablettes Alburnus alburns (L.) dans le lac de Sainte-Croix. Conséquences sur la croissances sur la croissance et la fecondité. Annales de Limnologie 23: 245-252.

Chumchal MM, Nowlin WH, Drenner RW. 2005. Biomass-dependent effects of common carp on water quality in shallow ponds. Hydrobiologia 545: 271-177.

Church M. (2010) Gravel-bed rivers in Burt T, Allison R (Eds), Sediment Cascades: An Integrated Approach, 241-270. John Wiley and Sons, Chichester.

Church M, Hassan MA, Wolcott JF. 1998. Stabilizing self-organized structures in gravel-bed stream channels: Field and experimental observations. Water Resources Research 34: 3169-3180.Corenblit D, Steiger J, gurnell A, Tabacchi E. 2007. Darwinian origin of landforms. Earth Surface processes and Landforms 32: 20702073.

Darby SE. 2009. Reappraising the geomorphology-ecology link. Earth Surface Processes and Landforms 35, (3): 368-371.

ESRI. 2011. ArcGIS Desktop: Release 10. Redlands, CA: Environmental Systems Research Institute. 
Everard M. 2013. Britain's Freshwater Fishes. Princeton University Press, 6 Oxford Street, Woodstock, Oxfordshire.

FAME CONSORTIUM (2004). Manual for the application of the European Fish Index - EFI. A fish-based method to assess the ecological status of European rivers in support of the Water Framework Directive. Version 1.1, January 2005.

Fenton JD, Abbott JE. 1977. Initial movement of grains on a stream bed: the effect of relative protrusion. Proc. R.Soc. Lond. A. 352: 523-537.

Field-Dodgson MS. 1987. The effect of salmon redd excavation on stream substrate and benthic community of two salmon spawning streams in Canterbury, New Zealand. Hydrobiologia 154: 3-11.

Fitzmaurice P. 1983. Carp (Cyprinius carpio L.) in Ireland. Irish Fish. Invest. 23: 5-10. Forrester GE, Chace JG, McCarthy W. 1994. Diel and density-related changes in food consumption and prey selection by brook charr in a New Hampshire stream. Environ. Biol. Fish. 39: 301-311.

Frankiewicz P, Zalewski M, Biro P, Tatrai I, Przybylski M. 1991. The food of fish from streams of the northern part of the catchment area of Lake Balaton (Hungary). Acta Hydrobiologia 33: 149-160.

Garner P. 2005. Microhabitat use and diet of 0+ cyprinid fishes in a lentic, regulated reach of the River Great Ouse, England. Journal of Fish Biology 48: 367-382

Giles N. 2002. The nature of Barbel. Perca Press, 50 Lake Road, Verwood, Dorset.

Gottesfeld AS, Hassan MA and Tunnicliffe JF. 2008. Salmon bioturbation and stream process. American Fisheries Society Symposium 65: 175 - 193.

Greenhalgh M, 1999. Freshwater fish. The natural history of over 160 native European species. Octopus publishing group Ltd, 2-4 Heron Quays, London.

Greenhalgh M, 2001. The pocket guide to freshwater fish of Britain and Europe. Octopus publishing group Ltd, 2-4 Heron Quays, London.

Hartley PHT, 1947. The natural history of some British freshwater fishes. Proc. Zool. Soc. Lond. 117: 129-206.

Hassan MA, Gottesfeld AS, Montgomery DR, Tunnicliffe JF, Clarke GKC, Wynn G, Jones-Cox H, Poirier R, Maclsaac E, Herunter $H$ and Macdonald SJ. 2008. Salmon- 
driven bedload transport and bed morphology in mountain streams. Geophysical Research Letters 35: L0440 doi:10.1029/2007GL032997

Hellawell JM. 1971. The autoecology of the Chub, Squalius cephalus L. of the river Lugg and Afon Lynfi. III. Diet and feeding habits. Freshwater Biology 1: 369-387.

Hellawell JM. 1972. The growth, reproduction and food of the Roach Rutilus rutilus L. of the river Lugg, Herefordshire,. J. Fish Biol. 4: 469-486.

Hession WC, Wynn TM, Curran JC, Resler, LM. 2010. Preface: Geomorphology and vegetation: Interactions, dependencies, and feedback loops. Geomorphology 116: 203-205.

Hodge R, Brasington J, Richards K. 2009. Analysing laser-scanned digital terrain models of gravel bed surfaces: Linking morphology to sediment transport processes and hydraulics. Sedimentology 56: 2024-2043.

Holopainen IJ, Hyvarinen H. 1985. Ecology and physiology of crucian carp (Carassius carassius (L.)) in small Finnish ponds with anoxic conditions in winter. Verh. Internat. Verein. Limnol. 22: 2566-2570.

Huet M. 1949. Apercu des relations entre la pente et les populations piscoles des eaux courantes [overview of the relationship between the slope and fish populations in streams]. Schweiz. Z. Hydrol. Ecol. 11: 333-351.

IBM Corp. Released 2012. IBM SPSS Statistics for Windows, Version 21.0. Armonk, NY: IBM Corp.

Janković D, Trifunac M. 1978. Kompetitivni odnosi u ishrani ekonomski značajnih ciprinidnih vrsta riba u skadarskom jezeru. Ekologija 13: 111-112.

Janssen J. 1976. Feeding modes and prey size selection in the alewife (Alosa pseudoharengus). J. Fish. Res. BD. Can. 33: 1972-1975.

Janssen J. 1978. Feeding-behavior repertoire of the alewife, Alosa pseudoharengus, and the ciscoes Coregonus hoyi and C. artedii. J. Fish. Res. BD. Can. 35: 249-253.

Johansson L. 1987. Experimental evidence for interactive habitat segregation between Roach (Rutilus rutilus) and Rudd (Scardinius erythrophthalmus) in a shallow eutrophic lake. Oceologia 73: 21-27. 
Johnson MF, Reid I, Rice SP, Wood J. 2009. Stabilisation of fine gravels by netspinning caddisfly larvae. Earth Surface Processes and Landforms 34: 413-423.

Johnson MF, Rice SP, Reid I. 2010. Topographic disturbance of subaqueous gravel substrates by signal crayfish (Pacifastacus leniusculus). Geomorphology 123: 269278.

Johnson MF, Rice SP, Reid I. 2011. Increase in coarse sediment transport associated with disturbance of gravel river beds by signal crayfish (Pacifastacus leniusculus). Earth Surfaces Processes and landforms 36: 1680-1692.

Kennedy M, Fitzmaurice P. 1968. The biology of the bream, Abramis brama L. in Irish waters. Proc. R. Ir. Acad. 67 (5): 95-157.

Kennedy M, Fitzmaurice P. 1970. The biology of the tench, Tinca tinca L. in Irish waters. Proc. R. Ir. Acad. 69 (3): 31-82.

Kennedy M, Fitzmaurice P. 1972. Some aspects of the biology of the gudgeon Gobio gobio L. in Irish waters. J. Fish Biol. 4: 425-440.

Kennedy M, Fitzmaurice P. 1974. The biology of the Rudd, Scardinius erythrophthalmus L. in Irish waters. Proc. R. Ir. Acad. 74: 245-305.

Komar PD, Li Z. 1986. Pivoting analyses of the selective entrainment of sediments by shape and size with application to gravel threshold. Sedimentology 33: 425-436

Kondolf GM, Sale MJ and Wolman MG. 1993. Modification of fluvial gravel size by spawning salmonids. Water Resources Research 20: 2265 - 2274.

Kotlik P, Berrebi P. 2001. Phylogeography of the barbel (Barbus barbus) assessed by mitochondrial DNA variation. Mol. col. 10: 2177-2185.

Krumbein WC. 1941. Measurement and geological significance of shape and roundness of sedimentary particles. Journal of Sedimentary Petrology 11: 64-72.

Lachner EA. 1952. Studies of the biology of the cyprinid fishes of the chub genus Nocomis of Northwestern United States. American Midland Naturalist 48: 433-466.

Lammens EHRR. 1984. A comparison between the feeding of white bream (Blicca bjoerkna) and bream (Abramis brama). Verh. Internat. Werein. Limnol. 22: 886-890. 
Lammens EHRR, Geursen J, MacGillavry PJ. 1987. Diet shifts, feeding efficiency and coexistance of Bream Abramis brama, Roach Rutilus rutilus and White Bream Blicca Boerkna in hypertrophic lakes. Prov. V. Cong. Eur. Icthyol.: 153-162.

Losos B, Penaz M, Kibičkova J. 1980. Food and growth of fishes of the Jihalva river. Acta Sc. Nat. Brno. 14: 1-46.

Macdonald JS, King CA and Herunter H. 2010. Sediment and salmon: The role of spawning sockeye salmon in annual bed load transport characteristics in small, interior streams of British Columbia. Transactions of the American Fisheries Society 139: 758-767.

Mann RHK. 1973. Observations on the age, growth, reproduction and food of the Roach Rutilus rutilus L. in two rivers in Southern England. J. Fish Biol. 5: 707-736.

Mann RHK. 1974. Observations on the age, growth, reproduction and food of the Dace Leuciscus leuciscus L. in two rivers in Southern England. J. Fish Biol. 6: 237253.

Mann RHK. 1996. Environmental requirements of European non-salmonid fish in rivers. Hydrobiologia 323 (3): 223-235.

Marston RA. 1994. River entrenchment in small mountain valleys of the Western USA: Influence of beaver, grazing and clearcut logging. Revision of Geography 69: 11-15.

Matsuzaki SS, Usio N, Takamura N, Washitani I. 2009. Contrasting impacts of invasive engineers on freshwater ecosystems: an experiment and meta-analysis. Oecologia 158: 673-686.

Mihailova L. 1964. Vrhu biologiata na recnia kefal (Leuciscus cephalus L.) vr. Struma. Investia na zool. Inst. S muzei 17: 125-156.

Miller SA, Crowl TA. 2006. Effects of common carp (Cyprinus carpio L.) on macrophytes and invertebrate communities in a shallow lake. Freshwater Biology 51: 85-94.

Montgomery DR, Buffington JM, Peterson NP, Schuett-Hames D, Quinn TP. 1996. Stream-bed scour, egg burial depths, and the influence of salmonid spawning on bed surface mobility and embryo survival. Canadian Journal of Aquatics and Fisheries Science 53: 1061 - 1070. 
Moore JW. 2006. Animal ecosystem engineers in streams. Bioscience 56: 237-246.

Moore JW, Schindler DE and Scheuerell MD. 2004. Disturbance of freshwater habitats by andromous salmon in Alaska. Oecologia 139: 298-308.Moyle PB. 1984. America's carp. Nat. Hist. N.Y. 84: 43-50.

Naiman, RJ, Elliott, SR, Hellfield, JM, O'Keefe, TC. 2000. Biophysical interactions and the structure and dynamics of riverine ecosystems: the importance of biotic feedbacks. Hydrobiologia 410: 79-86.

Neill CR, Yalin, MS. 1969. Quantitative definition of beginning of bed movement. ASCE Journal of Hydraulic Division 95: 585-588.

Noble RAA, Cowx IG, Goffaux D, Kestemont P. 2007. Assessing the health of European rivers using functional ecological guilds of fish communities: standardising species classification and approaches to metric selection. Fisheries Management and Ecology 14: 381-392.

Nurminen L, Horppila J, Lappalainen J, Malinen T. 2003. Implications of rudd (Scardinius erythrophthalmus) herbivory on submerged macrophytes in a shallow eutrophic lake. Hydrobiologia 506: 511-518.Parkos JJ, Santucci VJ, Wahl DH. 2003. Effects of adult common carp (Cyprinus carpio) on multiple trophic levels in shallow mesocosms. Canadian Journal of Fisheries and Aquatic Science 60: 182-192.

Persson L. 1983. Food consumption and the significance of detritus and algae to intraspecific competition in Roach Rutilus rutilus in a shallow eutrophic lake. Oikos 41: 118-125.

Persson A, Svensson JM. 2006. Effects of benthivorous fish on biogeochemical processes in lake sediments. Freshwater Biology 51: 1298-1309.

Peterson DP, Foote CJ. 2000. Disturbance of small-stream habitat by spawning sockeye salmon in Alaska. Transactions of the American Fisheries Society, 129: 924934.

Piria M, Treer T, Aničić I, Safner R, Odak T. 2005. The natural diet of five cyprinid fish species. Agriculturae conspectus Scientificus 70: 21-28.

Politou CY, Economidis PS, I Sinis Al. 1993. Feeding biology of bleak, Alburnus alburnus, in lake Koronia, northern Greece. Journal of Fish Biology 43: 33-43. 
Ponton D, Gerdeaux D. 1988. Quelques aspects de l'alimentation de deux poissons planctonophages du lac leman: le corégone (Coregonus schinzii palea Cuv. Et Val.) et le gardon (Rutilus rutilus)). Bull. Fr. Pêche Pisic. 308: 11-23.

Prejs A. 1976. Fishes and their feeding habits. In Selected Problems in Lake Littoral Ecology (ed. E. Pieczinski), Warsaw Univ. Press, Warsaw, 155-171.

Prejs A, Jackowska H. 1978. Lake macropohytes as the food for Roach (Rutilus rutilus) and Rudd (Scardinius erythrophthalmus). Species composition and dominance relations in the lake and food. Ekol. Pol. 26: 429-438.

Pringle CM, Hamazaki T. 1998. The role of omnivory in a neotropical stream: separating diurnal and nocturnal effects. Ecology 79: 1860-1872.

Rask M. 1989. The diet of Roach and some other cyprinids in the northern Baltic sea. Aqua fenn. 19: 19-27.

Reinhardt L, Jerolmack D, Cardinale BJ, vanacker V, Wright J. 2010. Dynamic interactions of life and its landscape: feedbacks at the interface of geomorphology and ecology. Earth Surface Processes and Landforms 35: 78-101.

Rice SP, Stoffel M, Turowski JM, Wolf A. 2012a. Disturbance regimes at the interface of geomorphology and ecology, Earth Surface Processes and Landforms 37: 16781682.

Rice SP, Johnson MF, Reid I. 2012b. Animals and the Geomorphology of Gravel-bed Rivers in Church M, Biron P and Roy AG (Eds), Gravel-bed rivers: processes, tools, environments, 225-241. John Wiley and Sons, Chichester.

Roozen F, Lurling M, Vlek H, Kraan E, Ibelings BW, Scheffer M. 2007. Resuspension of algal cells by benthivorous fish boosts phytoplankton biomass and alters community structure in shallow lakes. Freshwater Biology 52: 977-987

Šenk OI, Aganović M. 1968. Prilog ispitivanju ishrane riba rijeke Vrbanje. Ribarstvo Jugoslavije 24: 77-83

Sibbing FA. 1991. Food capture and oral processing. In: Winfield, IJ \& Nelson, JS e.d. Cyprinid Fishes Systematics, biology and exploitation. Chapman and Hall, Bury St. Edmunds, pp 377-412. 
Smart GM, Aberle J, Duncan M, Walsh J. 2004. Measurement and analysis of alluvial bed roughness. Journal of Hydraulic Research 42: 227-237.

Sneed ED, Folk RL. 1958. Pebbles in the lower Colorado River, Texas: a study in particle morphogenesis. Journal of Geology 66: 114-150.

Statzner B. 2011. Geomorphological implications of engineering bed sediments by lotic animals. Geomorphology 157: 49-65. doi:10.1016/j.geomorph.2011.03.022

Statzner B, Sagnes P. 2008. Crayfish and fish as bioturbators of streambed sediments: assessing joint effects of species with different mechanistic abilities. Geomorphology 3: 267-287.

Statzner B, Fuchs U, Higler LWG. 1996. Sand erosion by mobile predaceous stream insects: implications for ecology and hydrology. Water Resources Research 32: 2279-2287.

Statzner B, Peltret O, Tomanova S. 2003a. Crayfish as geomorphic agents and ecosystem engineers: effect of a biomass on base flow and flood-induced transport of gravel and sand in experimental streams. Freshwater Biology 48: 147163.Statzner B, Sagnes P, Champagne J-Y, Viboud S. 2003b. Contribution of benthic fish on the patch dynamics of gravel and sand transport in streams. Water Resources research 39 (11): 1-17.

Viles HA. 1988. Introduction. IN Viles, H.A., ed., Biogeomorphology. Basil Blackwell, New York, 319-30.

Viles HA, Naylor LA, Carter NEA, Chaput D. 2008. Biogeomorphological disturbance regimes: progress in linking ecological and geomorphological systems, Earth Surface Processes and Landforms 33: 1419-1435.Vøllestad LA. 1985. Resource partitioning of Roach Rutilus rutilus and Bleak Alburnus alburnus in two eutrophic lakes in SE Norway. Holarctic Ecology 8: 88-92.

Vuković T, Ivanović B. 1971.Variranje duzine crevnog trakta nekih ciprinidnigh vrsta iz pritoza gornjeg toka rijeke Bosne. Ribarstvo Jugoslavije 23: 84-86.

Wanzenbock J. 1989. Prey detection in cyprinids during early development. Can. J. Fish. Aquat. Sci. 46: 995-1001.

Wheaton JM, Gibbins C, Waainright J, Larsen L, McElroy B. 2011. Preface: Multiscale Feedbacks in Ecogeomorphology. Geomorphology 126: 265-268. 
Winfield IJ, Peirson G, Cryer M, Townsend CR. 1983. The behavioural basis of prey selection by underyearling Bream (Abramis brama (L.)) and Roach (Rutilus rutilus(L.)). Freshwat. Biol. 13: 139-149.

Zhang Y, Richardson JS, Negishi JN. 2004. Detritus processing ecosystem engineerin and benthic diversity: a test fo predator-omnivore interference. Journal of Animal Ecology 73: 3162-3173. 
Table 1: Flow characteristics during water-working, treatment and entrainment phases.

\begin{tabular}{cccc} 
& \multicolumn{3}{c}{ Flow condition } \\
\cline { 2 - 4 } Flow parameters & Water-working & $\begin{array}{c}\text { Treatment (fish } \\
\text { exposure) }\end{array}$ & Entrainment \\
\hline Slope \% & 1.4 & 0 & 1.4 \\
\hline $\begin{array}{c}\text { Average velocity (0.6 } \\
\text { depth); } \text { m s }^{-1}\end{array}$ & 0.64 & 0.01 & 0.83 \\
\hline $\begin{array}{c}\text { Local bed shear } \\
\text { stress; } \mathbf{N ~ m}^{-2}\end{array}$ & 3.56 & 0.01 & 5.71 \\
\hline $\begin{array}{c}\text { Bed shear stress } \\
\text { corrected for sidewall; } \\
\mathbf{N} \text { m }^{-2}\end{array}$ & 3.38 & 0.01 & 5.48 \\
\hline $\begin{array}{c}\text { Shields' } \\
\text { dimensionless shear } \\
\text { stress parameter }\end{array}$ & 0.019 & 0.00050 & 0.031 \\
\hline \begin{tabular}{c} 
Reynolds number \\
\hline
\end{tabular} & 36000 & 908 & 37640 \\
\hline
\end{tabular}

Note: Local bed shear stress was corrected using Williams' (1970) empirical function and the corrected value was used to estimate Shields parameter values. 
Table 2: Microtopographic roughness (s.d. of surface elevations), inclination index, total number of points classed as protruding and the $P$-value for the difference between substrates before and after exposure to Barbel during the treatment phase. Values represent means $\pm \mathrm{SE}(n=5)$.

\begin{tabular}{cccc}
\hline & $\begin{array}{c}\text { After water- } \\
\text { working }\end{array}$ & $\begin{array}{c}\text { After exposure to } \\
\text { Barbel }\end{array}$ & $\boldsymbol{P}$-value \\
\hline s.d. of surface elevations & $4.04 \pm 0.11$ & $4.8 \pm 0.11$ & 0.00044 \\
Inclination index & $0.035 \pm 0.025$ & $-0.075 \pm 0.0089$ & 0.004 \\
\hline
\end{tabular}


Table 3: Characteristics of sediment movements by Barbel. ND = no data

\begin{tabular}{lcccc} 
& & \multicolumn{3}{c}{ Grain size (mm) } \\
\cline { 3 - 5 } & & $\mathbf{5 . 6 - 8}$ & $\mathbf{8 - 1 1}$ & $\mathbf{1 1 - 1 6}$ \\
\hline \multirow{2}{*}{ Displacement distance $(\mathbf{m m})$} & Mean $( \pm 1 . \mathrm{SE})$ & ND & $41 \pm 19.71$ & $31 \pm 13.44$ \\
& Max & ND & 301 & 95 \\
\multirow{2}{*}{ Displacement direction (\%) } & Upstream & ND & 71 & 20 \\
& Downstream & ND & 29 & 80 \\
\hline
\end{tabular}


Table 4: Habitat preferences and feeding behaviours of thirteen common UK Cyprinids.

\begin{tabular}{|c|c|c|}
\hline Common name & Habitat ${ }^{1}$ & Feeding behaviour \\
\hline Barbel Barbus barbus & Barbel zone & $\begin{array}{l}\text { Benthic feeding. Eat bed dwelling invertebrates; freshwater } \\
\text { shrimp, water snails, caddis larvae, mayfly nymphs and in silty } \\
\text { or muddy areas, midge larvae. Will intercept food items which } \\
\text { fall into the, water and settle on the river bed } \\
\text { surface. } 2,3,4,5,6,7,8,9,16,11,13,23 .\end{array}$ \\
\hline Bleak Alburnus alburnus & Bream zone & $\begin{array}{l}\text { Feed close to the water surface on aquatic insect pupae, } \\
\text { nymphs rising through the water column and adults that have } \\
\text { hatched at the surface. When insects and plankton are scarce, } \\
\text { will graze on weed. } 2,3,8,15,16,17,18,19,20,21,23,32,40 \text {. }\end{array}$ \\
\hline $\begin{array}{l}\text { Bronze Bream Abramis } \\
\text { brama }\end{array}$ & Bream zone & $\begin{array}{l}\text { Primarily benthic feeding, foraging in mud and silt for insect } \\
\text { larvae, }{ }_{2,3,13 a i l s} \text { small bivalve molluscs and } \\
\text { worms. }\end{array}$ \\
\hline $\begin{array}{l}\text { Carp (Common, Mirror and } \\
\text { Leather) Cyprinus carpio }\end{array}$ & Bream zone & $\begin{array}{l}\text { Omnivorous, feeding on a varied diet of bed-dwelling } \\
\text { macroinvertebrates; bloodworms, aqutic mud-dwelling worms, } \\
\text { water snails, freshwater mussels and crustaceans, Will eat } \\
\text { weed and terrestrial food items that fall into the water., }\end{array}$ \\
\hline Chub Leuciscus cephalus & $\begin{array}{l}\text { Barbel and Bream } \\
\text { zone }\end{array}$ & $\begin{array}{l}\text { Opportunistic feeder. Feed on various aquatic invertebrates eg. } \\
\text { Caddis larvae and stonefly nymphs from the river bed, rising } \\
\text { nymphs and pupae, and adult insects on the water surface. Will } \\
\text { feed on fruits, seeds, slugs, earthworms and insect larvae } \\
\text { which fall into the water. Will eat plant material, amphibians and } \\
\text { fish. } 2,3,8,9,10,11,12,13,14,15,23,28 .\end{array}$ \\
\hline $\begin{array}{l}\text { Crucian Carp Carassius } \\
\text { carassius }\end{array}$ & Bream zone & $\begin{array}{l}\text { Primarily benthic feeding. Eat midge larvae, water hog-lice, } \\
\text { freshwater shrimps, aquatic worms, small molluscs and other } \\
\text { invertebrates in silt or weed. Fish will supplement benthic diet } \\
\text { with planktonic crustaceans (Daphnia and Cyclops). }\end{array}$ \\
\hline Dace Leuciscus leuciscus & $\begin{array}{l}\text { Grayling, Barbel } \\
\text { and Bream zones }\end{array}$ & $\begin{array}{l}\text { Feed almost entirely on invertebrates; mayfly and stonefly } \\
\text { nymphs, midge and blackfly larvae and pupae, caddisflies and } \\
\text { flies, hawthorn flies, black gnats and crane flies. Will graze on } \\
\text { algae. Mature specimens have been known to feed on small } \\
\text { fish and amphibians. } 2,3,23,27 .\end{array}$ \\
\hline Gudgeon Gobio gobio & $\begin{array}{l}\text { Barbel and } \\
\text { Grayling zones }\end{array}$ & $\begin{array}{l}\text { Benthic feeder, preying on aquatic invertebrates. Specifically, } \\
\text { midge larvae and pupae, blackfly larvae and pupae, and } \\
\text { freshwater shrimp. } 2,3,15,23,43 \text {. }\end{array}$ \\
\hline Ide Leuciscusidus & Bream zone & $\begin{array}{l}\text { In their first year, fish feed on cladocerans and copepods, } \\
\text { supplementing these food types with weed. After a year, fish } \\
\text { feed on a variety of invertebrates including nymphs, caddis } \\
\text { larvae, mayflies and stoneflies, water snails and freshwater } \\
\text { clams and freshwater shrimps. Mature fish often become wholly } \\
\text { or particialy piscivorous. }\end{array}$ \\
\hline Roach Rutilus rutilus & Bream zone & $\begin{array}{l}\text { Omnivorous. Eat insect larvae, nymphs and pupae, freshwater } \\
\text { shrimps, plant material, algae and seeds that fall into the } \\
\text { water. }{ }^{2,3,15} \text { (19,23,24,25,29,30,31,32,36,37,38. }\end{array}$ \\
\hline $\begin{array}{l}\text { Rudd Scardinius } \\
\text { erythrophthalmus }\end{array}$ & Bream zone & 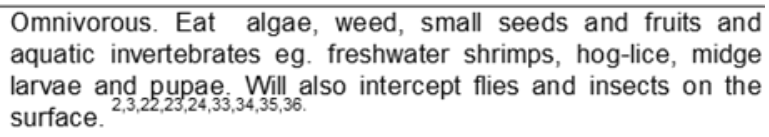 \\
\hline Silver Bream Blicca bjoerkna & Bream zone & $\begin{array}{l}\text { Omnivorous, feeding on algae, weed and invertebrates from the } \\
\text { bed eq. freshwater shrimps, hog-lice, small moluscs and midge } \\
\text { larvae. } 23,30,32,45,46 \text {. }\end{array}$ \\
\hline Tench Tinca tinca & Bream zone & $\begin{array}{l}\text { Benthic feeder. Eat insect larvae, worms and water-hog lice } \\
\text { from bed sediments. } 2,23,45 \text {. }\end{array}$ \\
\hline
\end{tabular}

References: ' ${ }^{1}$ Huet, 1949. ${ }^{2}$ Greenhalgh, 2001. ${ }^{3}$ Greenhalgh, 1999. ${ }^{4}$ Mann, 1996. ${ }^{5}$ Baras, 1997. ${ }^{6}$ Baras \& Cherry, 1990. ${ }^{7}$ Bischoff \& Freyhof, 1999. ${ }^{8}$ Piria et al., 2005. ${ }^{9}$ Šenk \& Agnanović, 1968. ${ }^{10}$ Mihailova, $1964 .{ }^{11}$ Adámek and Obrdlík, 1977. ${ }^{12}$ Janković and Trifunac, 1978. ${ }^{13}$ Losos et al., 1980 ${ }^{14}$ Frankiewicz et al., 1991. ${ }^{15}$ Garner, 2005. ${ }^{16}$ Vuković \& Ivanović, 1971. ${ }^{17}$ Bohl 1980. ${ }^{18}$ Bohl, 1982. ${ }^{19}$ Vollestad, 1985 ${ }^{20}$ Chappaz et al., 1987. ${ }^{21}$ Politou et al. 1993. ${ }^{22}$ Nurminen et al., 2003 ${ }^{23}$ Everard, 2013. ${ }^{24}$ Prejs \& Jackowska, 1978. ${ }^{25}$ Persson, 1983. ${ }^{26}$ Mann 1973. ${ }^{27}$ Mann 1974. ${ }^{28}$ Hellawell, $1971 .{ }^{29}$ Hellawell, 1972. ${ }^{30}$ Lammens et al., 1987. ${ }^{31}$ Ponton \& Gerdeaux, $1988 .{ }^{32}$ Rask, $1989 .{ }^{33}$ Prejs, $1976 .{ }^{34}$ Hartley, $1947 .{ }^{35}$ Kennedy \& Fitzmaurice, 1974. ${ }^{36}$ Johansson, 1987. ${ }^{37}$ Winfield et al., 1983. ${ }^{38}$ Brabrand, 1984. ${ }^{39} \mathrm{Cala}, 1970 .{ }^{40}$ Wanzenbock, 1989 ${ }^{41}$ Fitzmaurice, 1983. ${ }^{42}$ Moyle, 1984. ${ }^{43}$ Kennedy \& Fitzmaurice, 1972. ${ }^{44}$ Kennedy \& Fitzmaurice, 1968. ${ }^{45}$ Kennedy \& Fitzmaurice, 1970. ${ }^{46}$ Lammens, 1984. ${ }^{47}$ Holopainen \& Hyvarinen, 1985. 

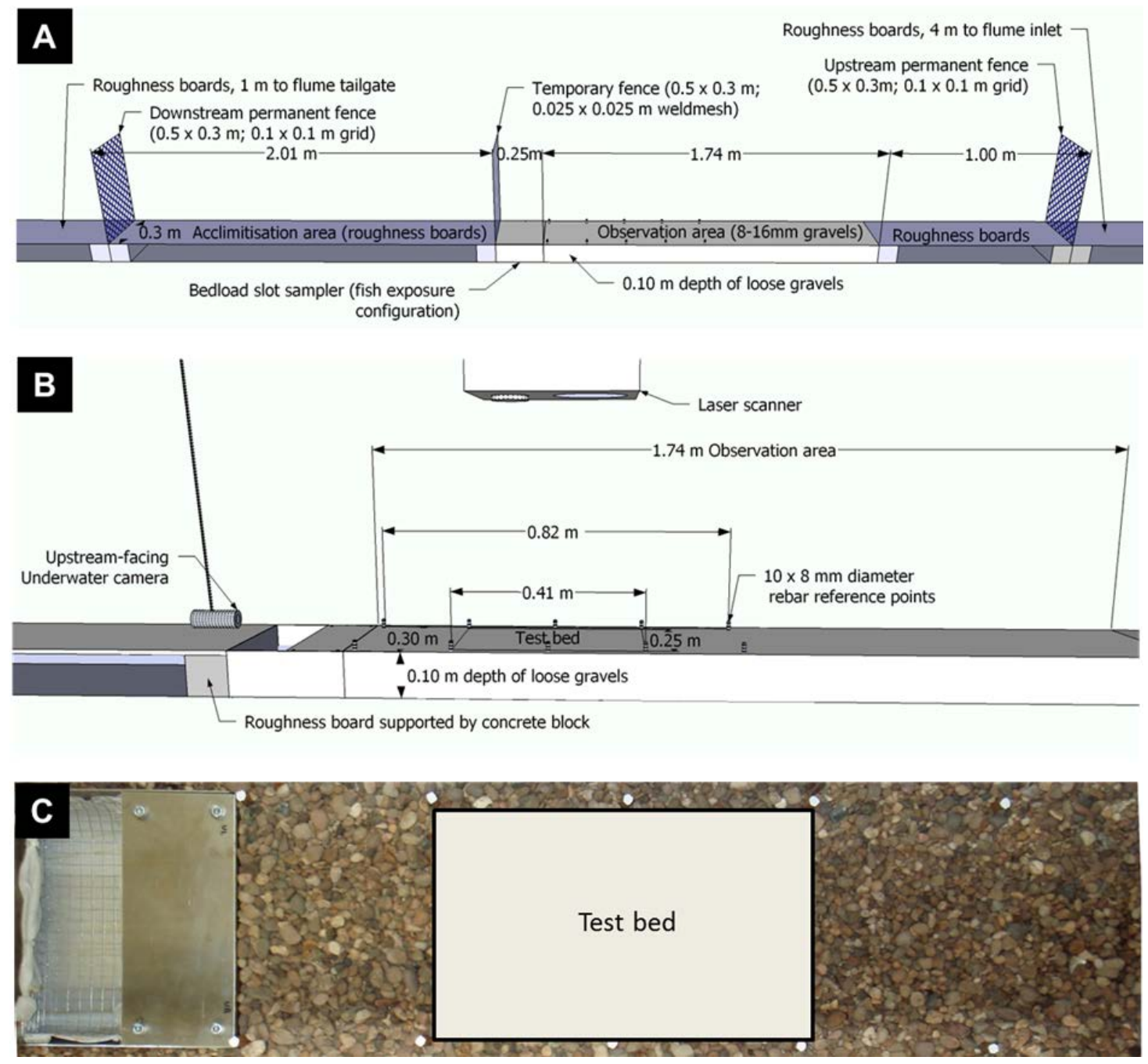

Figure 1: A 3D model of the flume setup whilst fish were in the channel, during the acclimatisation period. Removal of the central, temporary fence allowed fish free access to the $5 \mathrm{~m}$ long experimental enclosure during experiments. B 3D model of the flume setup during water-working and entrainment phases. Model shows the spatial locations of the underwater camera, bedload slot sampler, laser scanner and test bed. C Aerial photograph of the bedload slot sampler (entrainment configuration) and test bed. Note: flow from right to left in all images. 

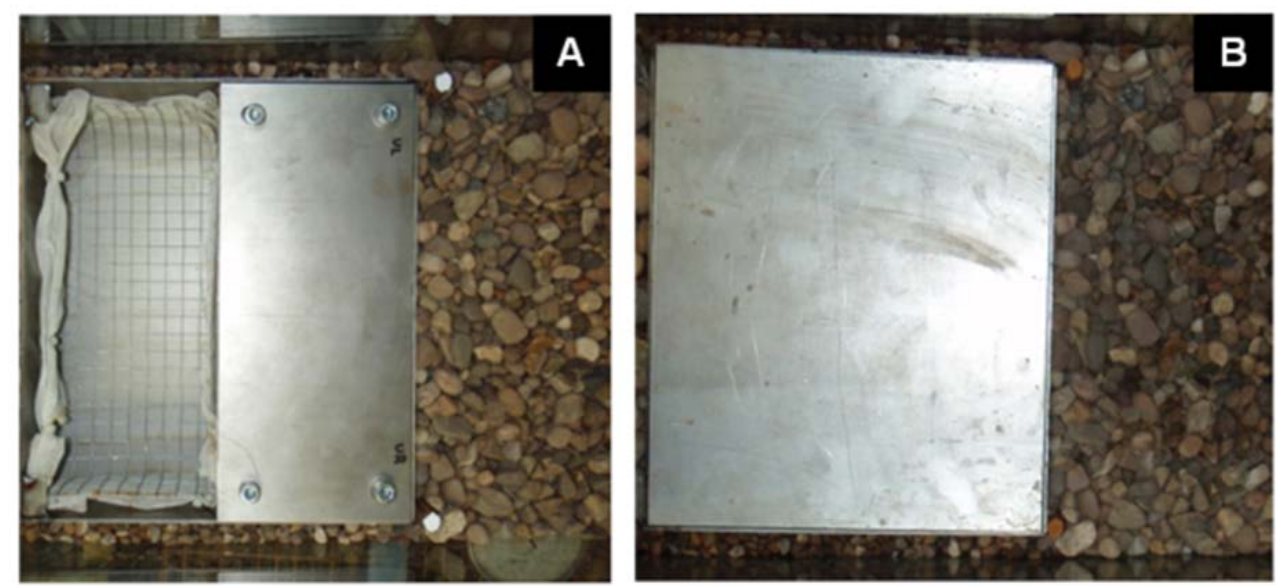

Figure 2: A Bedload slot sampler in "entrainment" (Figure 1B) and B "fish exposure" configurations (Figure 1A). Note: flow direction from right to left. 


W
With fish experimental
treatment

B

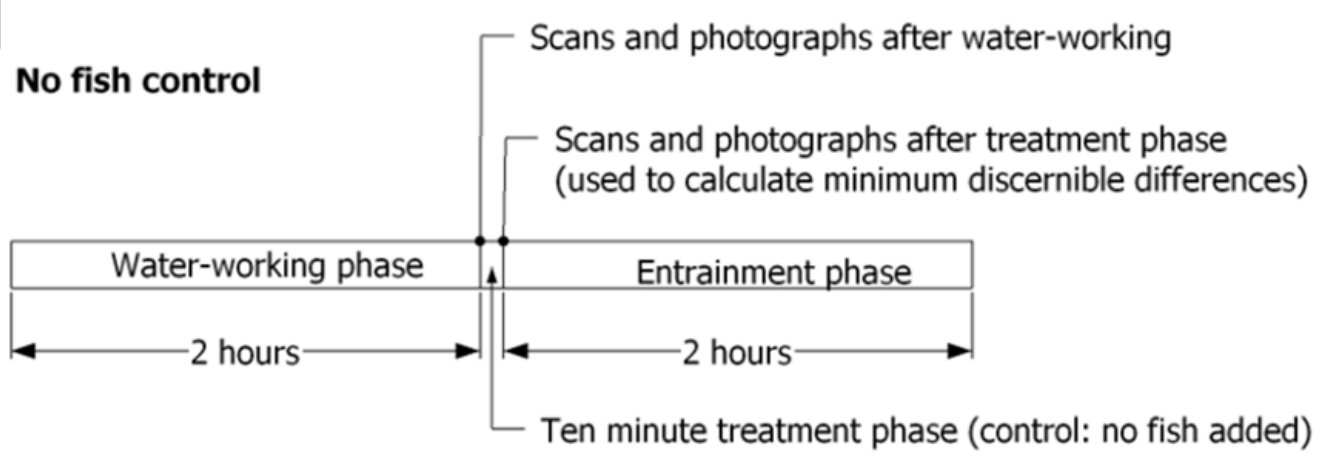

3 Figure 3: Schematic diagram presenting the experimental procedure for A "with fish" experimental treatment and B "no fish" control 


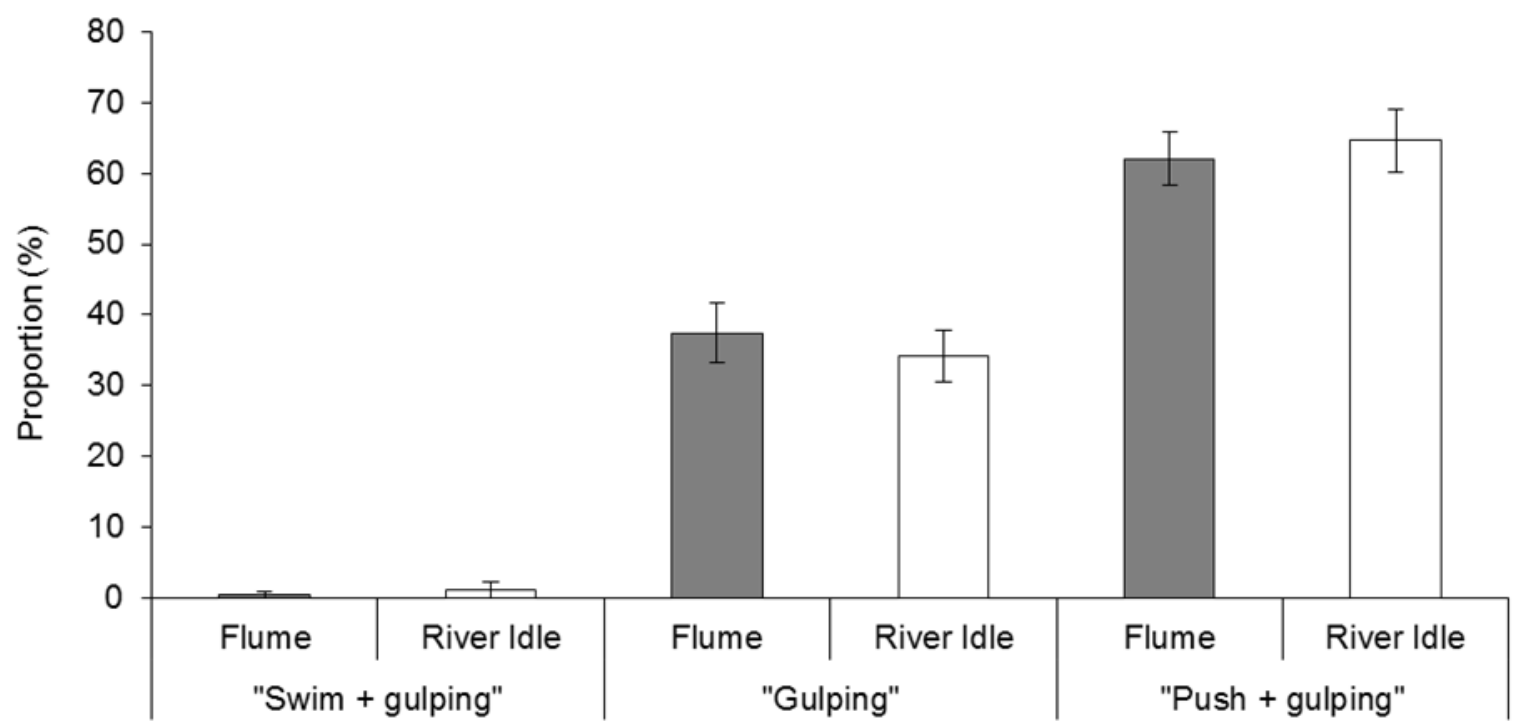

5

6

7 Figure 4: The prevalence of different Foraging behaviours for Barbel during ex-situ

8 flume experiments $(n=5)$ and in-situ experiments in the River Idle $(n=4)$. Values 9 represent means \pm SE. 


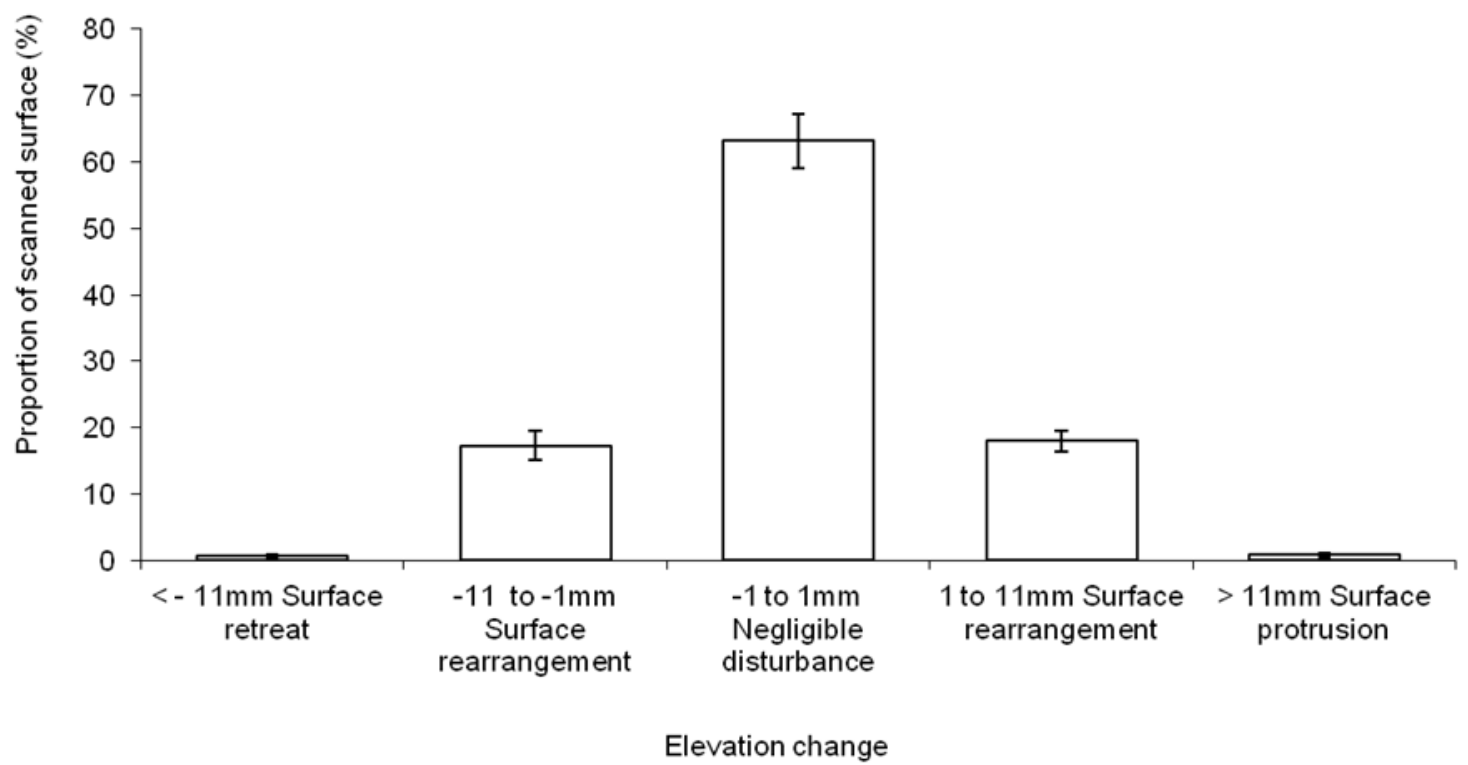

Figure 5: Mean surface elevation change as a percentage of the DEM surface area (5.6-16mm gravel surfaces, $0.48 \times 0.28 \mathrm{~m}$ ) before and after 4 hours of Barbel activity in a low-velocity flow (0.01 m s-1). Values represent means ( $n=5, \pm S E)$. 


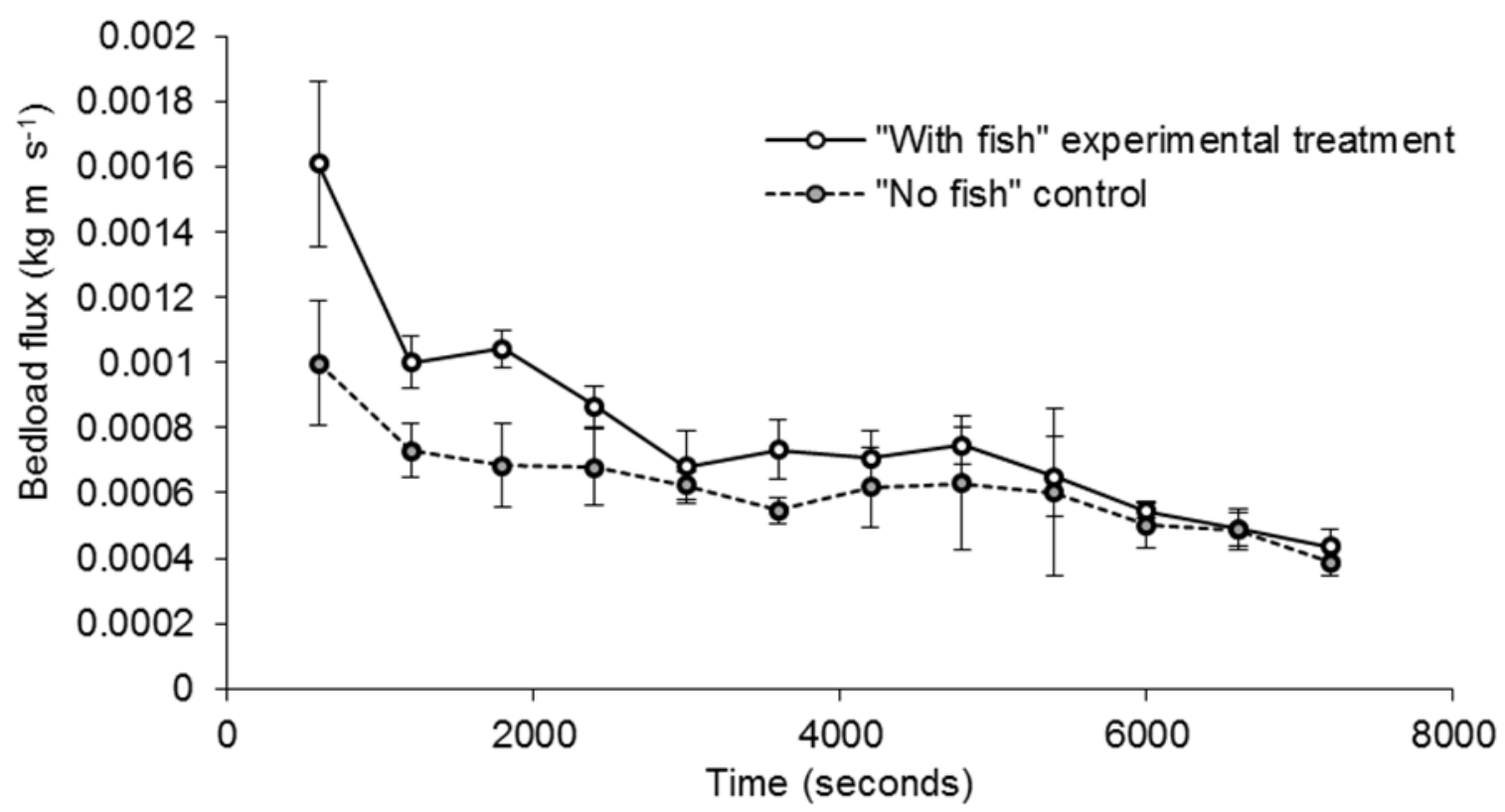

18 Figure 6: Bed load flux (measured averages for 10 minute periods) during phase 3 19 (entrainment phase). Presented are means \pm SE for "with fish" experimental treatment 20 (solid line, $n=5$ ) and "no fish" control (dashed line, $n=6$ ) runs. 

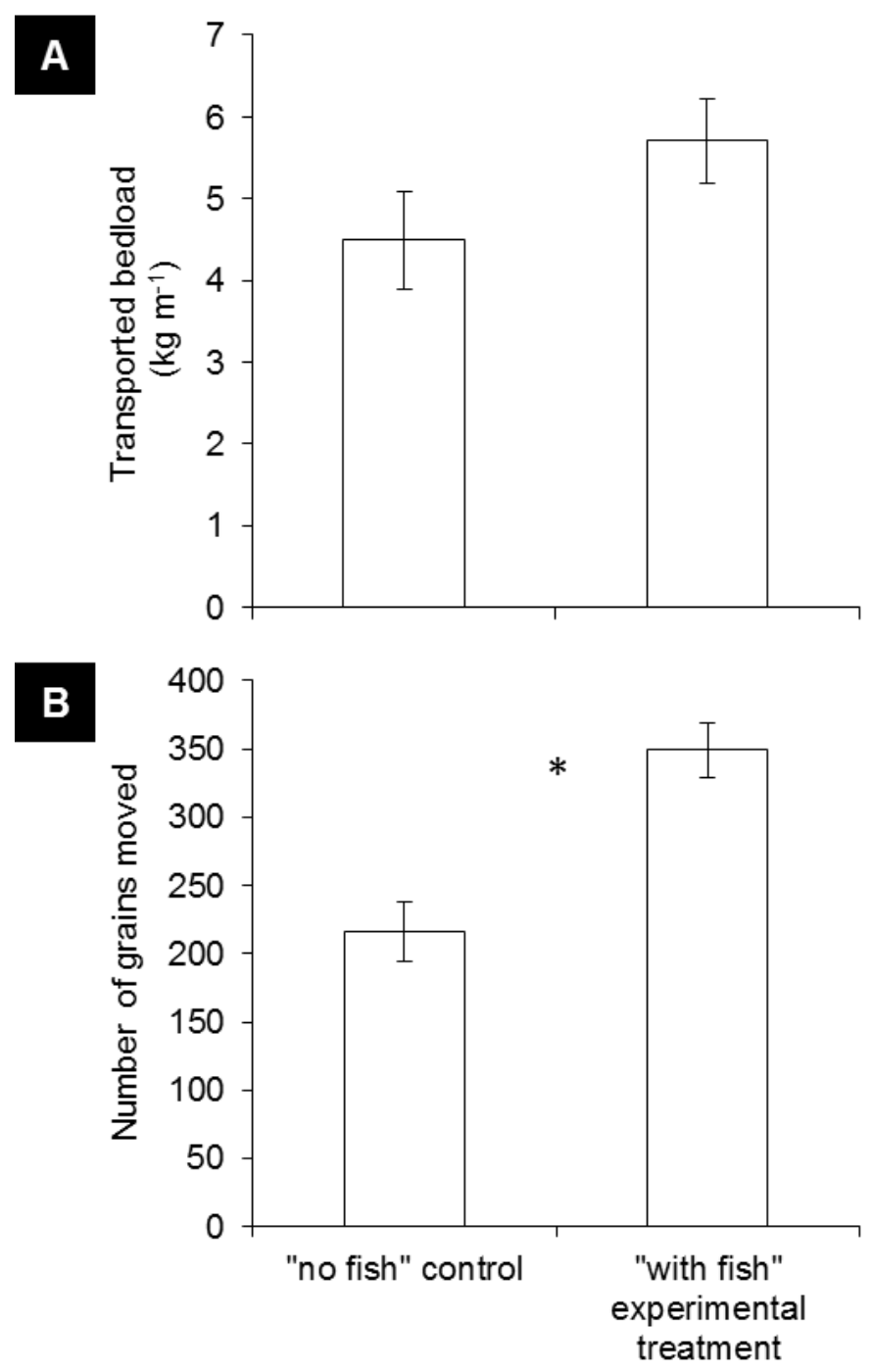

23 Figure 7: The impact of foraging Barbel on the stability of water-worked, gravel bed 24 textures. Presented are the $\mathbf{A}$ total transported mass and $\mathbf{B}$ total number of 25 transported grains at the end of the 120 minute entrainment period (phase 3), for "no 26 fish" control and "with fish" experimental treatment runs. Presented points represent means $\pm S E$ ("no fish" control n=6, "with fish" experimental treatment $n=5$ ). An asterisk

28 above a pair of points indicates that the difference between "no fish" control and "with 29 fish" experimental treatment values is significant. 